\title{
SOSYAL MEDYA VE VATANDAŞ ODAKLI KAMU HIZMETİ YAKLAŞIMI
}

\author{
Özge UYSAL ŞAHIN
}

Doç.Dr., Çanakkale Onsekiz Mart Üniversitesi, Çanakkale Uygulamalı Bilimler Yüksek Okulu / TÜRKIYE, E-mail: uysal83@gmail.com

\section{$\ddot{O Z Z E T}$}

Web 2.0 teknolojileriyle beraber gelissim gösteren sosyal medya uygulamaları hayatın her alanını etkilemeye başlamıștır. Bloglar, YouTube, Facebook, Twitter ve Linkedn gibi uygulamaların kullanıcı sayısı artarken bunları sadece kişiler değil özel ve kamu kurum ve kuruluşlarıyla STK'lar da kullanmaya başlamıştır. Özellikle Yeni Kamu Yönetimi (YKY) yaklaşımıyla beraber bir dönüşüm yaşayan kamu sektöründe sosyal medyanın önemi artmaktadır. YKY çerçevesinde vatandaş odaklı kamu hizmeti anlayışını hayata geçirmeye çalışan devletler için teknolojik ilerlemelerin göz arda edilmesi mümkün görünmemektedir. Bu bağlamda, sosyal medya uygulamaların vatandaş odaklı hizmet anlayışı için ne gibi bir etki yaratacağg, artı ve eksi tarafları ile bu uygulamaların söz konusu hizmet anlayışı çerçevesinde nasıl kullanılabileceği sorularına cevap bulmak gerekmektedir. Bu çalışmada da, bu sorular cevaplandırılmaya çalışılarak bir değerlendirme yapılacak ve önerilerde bulunulacaktır.

Anahtar Sözcükler: Web 2.0, Sosyal Medya, Vatandaş Odaklı Kamu Hizmeti, E-Devlet

JEL Kodu: H40, O33, O38 


\title{
$\int\left(\begin{array}{c}\text { Journal of Life } \\ \text { Economics }\end{array}\right.$ \\ SOCIAL MEDIA AND CITIZEN CENTERED PUBLIC SERVICE APPROACH
}

\begin{abstract}
Social media applications that have developed along with Web 2.0 technologies have begun to affect every aspect of life. As the number of users of applications such as Blogs, YouTube, Facebook, Twitter and Linkedn increased, Not only individualsbut also private and public institutions and organizations with NGOs started to use them. Especially in the public sector, which is transformed with the approach of New Public Management (NPM), the importance of social media is increasing. It seems unlikely that technological advancements will be considered for governments that are trying to pass the citizen-centered public service perception within the framework of NPM. In this context, it is necessary to answer the questions of how social media applications will have an impact on citizencentered service perception, plus and minus sides and how these applications can be used within the context of that service concept. In this study, an evaluation and suggestions will be made by trying to answer these questions.
\end{abstract}

Key Words: Web 2.0, Social Media, Citizen-Centered Public Service, e-Government

JEL Codes: H40, O33, O38

\section{GíRiș}

Sosyal medya, günümüzde giderek daha çok insan tarafından kullanılan en önemli iletişim araçlarından biri haline gelmiştir. Artan çeşitliliği ile sosyal medya, zaman ve mekân sınırlaması olmaksızın, paylaşım, tartışma ve fikir alışverişinin yapıldığı, yani etkileşeme imkan veren bir ortam sunmaktadır. İkinci nesil internet hizmetlerini, yani toplumsal iletişim siteleri, vikiler gibi internet kullanıcılarının ortaklaşa ve paylaşarak yarattığı sistemi ifade eden Web 2.0 teknolojisinin gelişimi, ikinci medya çağı olarak adlandırılan sosyal medyanın doğuşunda temel etken olmuştur.

Son yıllarda, sosyal medyanın dünyada yaygınlaşarak yoğun bir şekilde kullanılmaya başlaması, kişilere ve kurumlara iletişim, tanıtım, hizmet sunumu gibi birçok konuda önemli fırsatlar sağlamaktadır. Yalnızca günlük hayatta ve iş dünyasında değil, aynı zamanda kamu sektörü ve siyasal hayatta da giderek tercih edilen bir iletişim aracı haline gelmektedir. Merkezi ve yerel yönetimler için artık sosyal medya olmazsa olmaz bir araç olma yolunda ilerlemektedir. Hatta siyasiler ve yöneticiler de karar alma ve ikna etme süreçlerinde sosyal medya araçlarını kullanmaya başlamışlardır. Bu bağlamda, kamu kurumlarında sosyal medya kullanımına ilişkin yol haritaları hazırlanmakta, sosyal medya üzerine kurumsal ve kişisel stratejiler geliştirilmektedir.Kamu kurumları, gerçekleştirdikleri hizmetler konusunda vatandaşlara bilgi verip onlarla bu konuda fikir alış verişi yapmak, uygulamalarda ya da alacakları kararlarda halkın katılımını sağlamak için sosyal medyayı kullanmaktadırlar. Özellikle devlet işlemlerini internet üzerinden kolayca yapılmasına olanak sağlayan e-devlet uygulamalarıyla sosyal medya araçları entegre hale getirilmeye çalışılmaktadır.

Sosyal medyanın kamu sektöründe giderek daha çok kullanılır hale gelmesi, sosyal medyanın, YKY yaklaşımı ile öne çıkan vatandaş odaklı kamu hizmeti anlayışına hizmet edip etmeyeceği, edecekse nasıl edeceği, ne gibi artılar sunup hangi riskleri taşıdığı gibi bir takım soruları beraberinde getirmektedir. Vatandaş odaklı kamu hizmeti anlayışıyla, şeffaflık, hesap verebilirlik, demokrasi, katılımcılık, erişebilirlik ve verimlilik gibi birçok kavram kamu yönetiminde öne çıkarken, sosyal medyanın gelişiminin bu süreci destekleyip güçlendireceği 


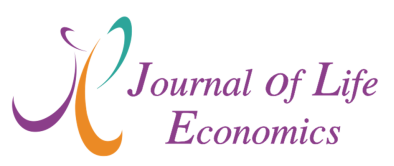

düşünülmektedir. Bununla beraber, bazılarına göre sosyal medya bu anlayışı desteklemekten öte dönüştürmektedir. Vatandaş odaklı hizmet anlayışında vatandaşlar daha çok, hizmetlerin "alıcısı" iken, sosyal medyanın kamu sektöründe etkin olmasıyla hizmetlerin "üreticisi/yapıcısı" haline gelmeye başlamışlardır. Bu bağlamda, çalışmada da bir yandan yukarıdaki sorulara yanıt aranırken, bir yandan da sosyal medyanın vatandaş odaklı kamu hizmeti anlayışı için bir firsat mı yoksa bir tehdit mi olduğu anlaşılmaya çalışılacaktır. Sosyal medya- vatandaş odaklı kamu hizmeti entegrasyonunun nasıl sağlanabileceği konusunda çeşitli önerilerde bulunup değerlendirme yapılarak çalışma sonlandırılacaktır.

\section{SOSYAL MEDYA KAVRAMI}

Tim O'Reilly tarafından 2004'te kullanılmaya başlayan Web 2.0, ikinci nesil internet hizmetlerini - toplumsal iletişim sitelerini, vikileri, iletişim araçlarını, yani internet kullanıcılarının ortaklaşa ve paylaşarak yarattığı sistemi ifade etmektedir. Web 2.0, işbirliğini, yaratıcılığı ve bağlantıyı teşvik eden yeni nesil siteleri içerir. Web 2.0, çeşitli siteleri ve hizmetleri ile kullanıcı tarafından üretilen içeriğin yanı sıra daha dinamik ve etkileşimli web sitelerini büyük ölçekte bir araya getiren bir platformdur (O'Reilly, 2005).Web 2.0, belirli bir teknolojinin parçası değil, insanların herhangi bir zamanda birbirlerine bağlanmasına ve ortak çalışmasına olanak tanıyan bir grup çevrimiçi iletişim platformudur. İnteraktifliğe ve iletişime dayalı Web 2.0 teknolojileri içinde genel olarak birçok farklı uygulama mevcuttur. Kullanılan en popüler uygulamalar arasında, viki'ler Twitter (veya mikro bloglama), RSS özet akışları ve Linkedln, Facebook gibi sosyal ağlar, Youtube, Google uygulamaları ve blog sayfaları bulunmaktadır (Reicharhardt, 2010).

Web 2.0 ile birlikte ortaya çıkan sosyal medya ise, kullanıcı tarafından içeriğin oluşturulmasına ve değiştirilmesine imkan tanıyan bir dizi internet tabanlı uygulamayı ifade etmektedir (Kaplan and Haenlein 2010). Sosyal medyayı uygulamaları aracılığıyla kullanıcılar çeşitli konular, ürünler veya hizmetler hakkına görüşlerini, deneyimlerini paylaşıp, diğer kullanıcılardan fikir alabilir, çeşitli tartışmaların içine girebilir ve hatta bazı hizmetler sunup bunların reklamını yapabilirler. Kent (2010) ise, sosyal medyayı "iki yönlü etkileşime ve geri bildirime izin veren etkileşimli bir iletişim kanalı" olarak tanımlamıştır. Safko (2009)'ya göre de sosyal medya, çevrimiçi olarak bir araya gelen, bilgi ve fikirlerini bu yolla paylaşan insan toplulukları ve bunların faaliyetleri ile davranışlarını ifade etmektedir

Tüm bu tanımlamalardan hareketle, Khan (2015)'ın ifade ettiği gibi sosyal medya, kullanıcılara bilgi, fikir ve çıkar paylaşma fırsatları sunarak etkileşimleri kolaylaştıran web siteleri ve çevrimiçi araçlar olarak özetlenebilir.Sosyal medya yalnızca bir bilişim teknolojisi uygulaması değildir, aynı zamanda bireylerin birbirleriyle etkileşim, iletişim ve bağlantı kurma biçimlerini etkileyen önemli bir iletişim aracıdır. Sosyal medya metin, ses, video, resim paylaşımına olanak sağlamakta, bu özelliği ile de bireylerin ihtiyaç duydukları bilgilere erişimini kolaylaştırmakta, kullanıcılara geniş bir kullanım imkanı sunarak büyük bir insan ağı vasıtasıyla istedikleri ilişkiyi kurma fırsatı vermektedir. Artık bireyler sadece izleyici veya okuyucu değil, doğrudan bilgi yayan aktörler haline gelmektedirler. Sosyal medya araçlarını kullanarak insanlar, düşüncelerini, fikirlerini, deneyimlerini küresel çapta paylaşma imkanı bulmaktadırlar (Solis and Breakenridge, 2009; Landsbergen, 2010).Başlica sosyal medya araçları ise şöyledir (Taşçı, 2010):

- Bloglar (Web günlükleri ): Blogger, Wordpress vb

- Mikrobloglar: Twitter, vb.

- Sosyal ağlar: Facebook, Cyworld, Bebo, Hi5, LinkedIn, vb

- Açık kaynak ansiklopediler: Wikipedia, Wikispaces, Turkcebilgi, vb

- Sosyal bookmarking (imleme ): Delicious, Fousquare vb. 


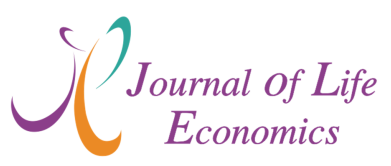

- Sosyal haber imleme: Digg, Reddit, Mixx, vb.

- Anlık mesajlaşma uygulamaları: Skype, Whatsapp, vb.

- Resim, ses ve video paylaşımı: Flickr, Istagram, Last.fm, YouTube, Vine, vb.

- Forumlar: frmtr.com, vb.

- Sanal oyunlar: Secondlife.com, vb.

- Sanal topluluklar: Yahoo! Groups, vb

İçeriği kullanıcılar tarafından oluşturulmuş internet tabanlı uygulamaları kapsayan sosyal medyanın sınıflandırılmasına yönelik farklı ayrımlar bulunsa da en çok başvurulan sınıflandırma, sosyal medyayı ana amaçlarına bağlı olarak ikiyi ayıran sınıflandırma türüdür. $\mathrm{Bu}$ bağlamda, sosyal medya iki geniş kategoride gruplandırılabilir: a) Kullanıcıların metin, video, resim, müzik paylaştıkları anlatımlı/dışa vurumsal sosyal medya (expressive social media) ve b) Kullanıcıların bilgi ve içeriği genel olarak paylaştığı ve ortak bir amaç için birlikte çalıştığı katılımcı sosyal medyadır (collabarative social media) (Kotler, Kartajaya and Setiawan, 2010). Fakat kimi zaman her iki amacın birlikte gerçekleştirilebildiği sosyal medya uygulamalarına da rastlanmaktadır. Özellikle sanal topluluklar bu duruma örnek olarak gösterilebilir.

Sosyal medyada, iletişim ve işbirlikleri geleneksel iletişim araçları üzerinden kurularak geliştirilmiştir. Geleneksel iletişim araçları, yüz yüze görüşmeler, telefon görüş̧meleri, kağıt postalar, faksları vb. içermektedir. Bilgi ve iletişim teknolojilerinin ön plana çıkarttığı yeni nesil iletişim araçları ise; elektronik posta, anında mesajlaşma, sanal paylaşım, ve web konferans gibi uygulamaları içerir. Sosyal medya, şemsiye bir terimdir. En basit şekliyle, değer yaratmak için teknolojinin etkileşim sağlayarak sosyal entegrasyon yaratmasını ifade etmektedir (Serrat, 2010).

Sosyal medya, geleneksel medyaya bazı kısımları ile benzerken birçok yönüyle ayrılmaktadır. Sosyal medyanın geleneksel medyadan farkları şöyle ifade edilebilir (Klieber, 2009):

- Erişim:Hem geleneksel medya hem de sosyal medya teknolojileri herkesin genel bir kitleye erişebilmesine olanak tanımaktadır. Ama sosyal medya bunu daha da kolaylaştırmıştır

- Erişilebilirlik: Geleneksel medyada faaliyette bulunmak genellikle özel şirketlerin ve hükümetlerin sahipliğindedir; sosyal medya araçları genel olarak herkes tarafından az maliyetle veya maliyetsiz kullanılabilmektedir.

- Kullanılırlık:Geleneksel medya üretimi çoğunlukla uzmanlaşma ve eğitim gerektirmektedir. Sosyal medya için çoğunlukla bu geçerli değildir, yani herkes üretimde bulunabilmektedir.

- Yenilik:Geleneksel medya iletişimlerinde görülen zaman kaybı (günler, haftalar, hatta aylar) anında etki ve tepki gücüne sahip sosyal medya ile kıyaslandığında uzun olabilmektedir (Tepkilerin zaman aralığına kullanıcılar karar verir). Geleneksel medya da sosyal medya araçlarına adapte olmaktadır, dolayısıyla yakın zamanda bu farklılık ortadan kalkacaktır.

- Kalıcllk: Geleneksel medya yaratıldıktan sonra değiştirilemez (bir dergi makalesi basıldıktan ve dağıtıldıktan sonra aynı makale üzerinde değişiklik yapılamaz), oysa sosyal medya yorumlar veya yeniden düzenlemeyle anında değiştirilebilir.

Sosyal medya, sürekli güncellenebilmesi, çoklu kullanıma açık olması, sanal paylaşıma olanak tanıması gibi giderek kullanım alanı bulan bir araç haline gelmiştir. Sosyal medya uygulamalarında içeriği tamamen bireyler belirler ve bireyler birbirleri ile sürekli bu 


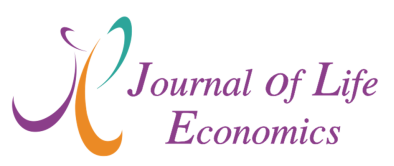

uygulamalar üzerinden etkileşim halindedirler. Diğer bir ifadeyle, zaman ve mekân sınırlaması olmaksızın paylaşımın, etkileşimin ve tartışmanın gerçekleştiği bir iletişim şeklidir. Bir uygulamanın yada web sitesinin bu tanıma uygun olması için şu özelliklere sahip olması gerekir (Erkul, 2009): a)Yayıncıdan bağımsız kullanıcıları olması, b)kullanıcı kaynaklı içerik olması, c)kullanıcılar arasında etkileşim olması ve d)zaman ve mekan sınırlaması olmamasıdır.

Mayfield (2008), sosyal medyayı en iyi anlaşılır şekilde; "beş farklı karakteristiğin tümüne ya da çoğuna sahip, bir tür yeni çevrimiçi medya grubu" olarak tanımlarken, bu beş farklı karakteristiği; katılım, açıklık, diyalog, topluluk ve birbirine bağlılık olarak belirtmiştir. Lerman (2007)'a göre ise sosyal medya sitelerinin dört ortak özelliği vardır. İlk olarak, kullanıcılar çeşitli medya türlerinde içerik oluşturabilir veya içeriklere katkıda bulunabilirler. İkincisi, kullanıcılar içerikleri etiketleyebilirler. Üçüncüsü, kullanıcılar içeriği ya aktif oylama ya da pasif kullanımla değerlendirebilirler. Son olarak, kullanıcılar diğer kullanıcılar ile ortak ilgi alanları tanımlayarak sosyal medya ağları oluşturabilirler.

Sosyal medya innovasyon anlaminda iki temel role sahiptir. Bu roller; "ortak üretim/yapım (co-creation)" ve "iletişim ağı (network)"dır. Sosyal medya ortak üretim/yapım konusunda bir arena olarak görülebilir. Çünkü kullanıcılar birlikte içeriğe katkı verip oluşturarak ortak bir üretim meydana getirirler. Wikipedia bu konuda temel bir örnektir (Kaplan ve Haenlein 2010). Sosyal medya aynı zamanda, grup üyeleri ve kaynak kişilerle paylaşımda bulunma, diyalog kurma ve iletişime geçme konusunda iletişim ağları sunan bir arena olarak da hizmet vermektedir (Kietzmann et al. 2011). Bununla birlikte, literatürde sosyal medyanın ortak üretim/yapım arenası olma işlevi ile iletişim ağı işlevi konusunda net bir ayrım bulunmamaktadır. Sosyal medya uygulamaları içinde bu iki işlevi birlikte yerine getirenler bulunmaktadır..

Bertot, Jaeger ve Grimes (2010)'e göre; sosyal medyanın dört büyük potansiyel gücü vardır: işbirliği, katılım, yetkilendirme ve zaman. Sosyal medya, toplumsal etkileşim çerçevesinde doğası gereği işbirliği ve katılım sağlar. Kullanıcılara bir diğer kişiyle iletişim kurma, sosyalleşmeyi sağlamak için topluluklar oluşturma, bilgi paylaşma ve böylece ortak amaç ve çıkarları gerçekleştirebilmeyi amaçlarlar. Sosyal medya, kullanıcılarına konuşma platformu sağladığ 1 için giderek güçlenmektedir. İnternete erişimi olan herkesin ucuz bir şekilde bilgi yayımlama veya yayın yapma imkanına sahip olması yönünde fırsat sunan sosyal medya, medyayı etkin ve demokratik bir yapıya sokar. Sosyal medya teknolojileri, zaman açısından ise, kullanıcıların gerçek zamanlı (anında) olarak bilgileri yayınlamasına izin verir.

İnsanların bilgi paylaşabilecekleri ve sınırlandırılmış bir çerçevede diğer bağlantı ve profillerdeki içerik ve bilgileri görüntüleyebilecekleri yeni bir iletişim biçimi sunan sosyal medyaya daha çok başvurarak, hükümet açıklık, şeffaflık, vatandaş katılımı, politika etkililiği, yönetim verimliliği, maliyet tasarrufu, iyi yönetişim, kamu çalışanı ve vatandaş memnuniyeti gibi kategoriler de dahil olmak üzere birçok konuda ilerleme kaydetmeyi ummamaktadır. Özelikle son dönemde oluşturulan politik stratejiler ve kullanıcı kılavuzları sosyal medyayla bu hedeflere ulaşmak için yapılmaktadır (Criado, Sandoval-Almazan and Gil-Garcia 2013). Özellikle erişim, paylaşım ve yayma gibi imkanlar sosyal medyayı bu bağlamda giderek öne çıkarmakta ve hükümetlerin başvurduğu birer araç haline getirmektedir.

Sosyal medya, hükümet ve vatandaşlar arasındaki ilişkiyi, tek veya çift yönlü bilgi değişiminden çoklu iletişim sürecine dönüştürmek için benzersiz bir fırsat sunmaktadır (Agostino, 2013). Devlet kurumları vatandaş odaklı olmaya, halkın hizmetlere erişimini, demokratik katılımı, etkililik, şeffaflık ve hesap verebilirlik gibi unsurları devlet yönetiminde öne çıkarmaya çalışmaktadırlar. Bu bağlamda, sosyal medyayı daha fazla ve etkin olarak 


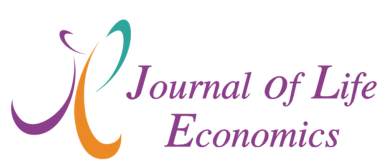

kullanmak zorundadırlar. Vatandaşların büyük çoğunluğu sosyal medya kullanmakta ve hükümetler onlarla bağlantı kurmak ve söz konusu hizmet anlayışının gereklerini yerine getirmek istiyorlarsa kendileri de bu uygulamalara başvurmaları gerekmektedir. Kamusal hizmetlerin daha etkin, etkili ve hızlı gerçekleştirilmesinde sosyal medya vazgeçilmez bir araç haline gelmektedir. Bu nedenle, devlet kurumları da sosyal medyayı tam olarak kullanabilmek için web tabanlı uygulamalarını ve altyapılarını belirli bir standartta geliştirmelidir.

Bahsedilen faydalarına rağmen, sosyal medya birçok riske de sahiptir. Sahte profillerin oluşturulması, kişisel bilgilere izinsiz erişim ve paylaşım ihtimali, dolandırıcılık, hakarete maruz kalma, siber suçlar ve dezenformasyon bu risklerin başında gelmektedir. Sosyal medyada bu risklerin en azından minimize edilmesi için gerekli önlemlerin alınması ve güvenlik konusunda iyileştirilmeye gidilmesi gerekmektedir. Vatandaş odaklı hizmet anlayışını tam anlamıyla hayata geçirmeye çalışan hükümetler için bu konu önem arz etmektedir. Bu bağlamda mevcut getiriler ve riskler göz önüne alınarak sosyal medya uygulamalarının vatandaş odaklı hizmet anlayışı için neyi ifade ettiği iyi değerlendirilmelidir. Bu uygulamaların kamusal hizmetlerde vatandaş odaklı bir yaklaşımı sağlamada ne kadar kullanılabileceği ve geliştirmek için neler yapılabileceği irdelenmelidir. Yoksa, vatandaş odaklı hizmet anlayışı için fırsattan öte bir tehdit mi olduğu sorusuna yanıt bulunmalıdır.

\section{VATANDAS ODAKLI KAMU HİZMETİ YAKLASIMI}

Küreselleşme, bilgi ve iletişim teknolojilerindeki hızlı değişim, vatandaşların değişen istek ve beklentileri gibi birçok gelişme YKY yaklaşımının bir yansıması olan vatandaş odaklı kamu hizmeti anlayışının ortaya çıkmasında belirleyici olmuştur. YKY yaklaşımı piyasa odaklı unsurların (toplam kalite yönetimi, etkinlik vb.) kamu yönetimi ve kamu hizmetleri içerisine yedirilmesi yanlısı olmasının yanında, vatandaşı da müşteri olarak gören bir yapıya sahiptir. Vatandaş odaklı anlayış da bu yapının üstüne oturmuş ve kamu hizmetleri için önemli bir dönüşümü başlatmıştır. Özellikle, bilgi ve iletişim teknolojilerinin vatandaşlar arasındaki etkileşimi arttırması, onların istek ve beklentilerinde artış yaşanmasına neden olmuştur. $\mathrm{Bu}$ durum devletler üzerinde bir baskı oluşmasına ve bir değiş̧im hareketinin başlamasına yol açmıştır.

Tüm bu gelişmelerin ışığında, vatandaş odaklı kamu hizmeti anlayışı işletme yönetiminde uygulanan müşteri odaklı yönetim anlayışının bazı teknik ve ilkelerinden yararlanarak, onları kamu yönetimi kalıbı içerisinde eriten, kar değil kamu hizmeti merkezli, müşteri değil vatandaşı esas alan; ancak, kamu yararı ve hakkaniyet ölçülerine bağlı kalarak, kamu hizmetini etkin-verimli-ekonomik ve kaliteli olarak sunmaya çalışan bir nitelik arz etmektedir. Bunun yanında, vatandaş odaklı hizmet anlayışı, kamuda hesap verme mekanizmalarının güçlendirilmesi, kamusal hizmetlerin sunumunda saydamlık, sağlanması, işyerlerini ve sivil toplum örgütlerini de içerecek biçimde vatandaşın hem politika oluşturmada, hem de uygulamada doğrudan doğruya devreye alınması, yani yönetişimin öne çıkarılması, devlete duyulan güvenin ve idarenin saygınlığının geliştirilmesi, hizmetin kalitesinin iyileştirilmesi gibi konuları da içermektedir (Karataş, 2007).Kısaca, vatandaş odaklı kamu hizmeti, kamusal hizmetlerin tasarım, sunum ve denetiminin her aşamasında vatandaş istek, beklenti ve kaygılarını dikkate alan, bazı özel sektör araçlarıyla bu süreçleri daha şeffaf, kolay erişilebilir ve kaliteli hale getirip vatandaşları süreçlere dahil eden, vatandaş memnuniyetini esas alan ve kamu yararını gözetmeye devam eden hizmet anlayışını ifade etmektedir (Uysal Şahin, 2014).

Vatandaş odaklı kamu hizmeti yaklaşımında vatandaşa hizmet öncelikli hale getirmek, hizmet sunumuna vatandaşı dâhil etmek, yüksek kalitede ve hızlı hizmet sunmak ile kaynak tahsisinde bu doğrultuda etkinliği sağlamak temel amaç olmuştur. Bu yaklaşım, merkeziyetçi 


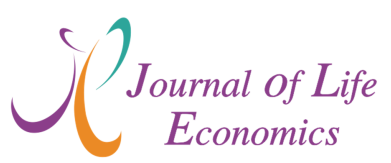

yapıdan daha desantralize yapıya, hantal ve hiyerarşik bürokratik yönetimden etkileşimli ve işlevsel yönetime, vatandaşı dışarıda bırakan karar alma sürecinden katılımcı uygulamaları benimseyen yapılara önem vermektedir (Uysal Şahin, 2014). Vatandaş odaklı yaklaşımda kalite, seçme, katılımcı denetim mekanizmaları ve hizmete erişebilirlik gibi etkileşimli bir vatandaş-devlet ilişkisi esastır (Baker, 1995). Bu bağlamda, vatandaş odaklı kamu hizmeti yaklaşımı başta ABD, Kanada ve İngiltere gibi gelişmiş ülkeler olmak üzere birçok ülkede giderek kabul görmeye başlamıştır. Her ne kadar kimi zaman müşteri odaklı yaklaşımla eşdeğer olarak kullanılsa da vatandaşı müşteri olarak görmenin sakıncası, adalet, eşitlik ve kamu yararı gibi noktalarda birbirinden ayrılmaktadır. Çünkü devlet, özel sektörün aksine, kamu yararı amacını gözetmeli, kamusal hizmetlerin sunulmasında herkese eşit haklar sunarak adil davranmalı ve ekonomik ve sosyal olarak yoksun olanları koruyarak gerekli yaşam koşullarını sağlamalıdır.

Kamusal hizmetlerin dönüştürülmesi amacıyla geliştirilen Güney Afrika'nın Batho Pele İlkeleri vatandaş odaklı hizmet sunumu için kusursuz bir politik çerçeve ve uygulama yöntemi oluşturmaktadır. Bu ilkeler sırasıyla şöyle ifade edilebilir (South Africa Department of Public Service and Administration, 2003):

- Danışma: Vatandaşlardan, aldıkları hizmetlerin düzeyi ve kalitesi hakkında bilgi alınmalı, ihtiyaçları göz önünde tutulmalı, hizmet standartları koyarak mevcut hizmetler yeniden düzenlenmeli ve gerekirse yeni hizmetler sunulmalıdır.

- Hizmet Standartları: Vatandaşlara, alacakları hizmetlerin düzeyi ve kalitesinin ne olacağı hakkında bilgi verilmeli ve vatandaşların en yüksek standartta hizmet aldıklarından emin olunmalıdır.

- Erişim: Tüm vatandaşların, özellikle dezavantajlı olanların, hizmetlere eşit şekilde ve kolayca erişimi sağlanmalıdır.

- Nezaket: Vatandaşlara nazikçe ve ehemmiyetle yaklaşılmalıdır.

- Bilgi: Vatandaşlara, almayı hak ettikleri hizmetler hakkında tam ve doğru bilgi verilmelidir.

- Açıklık ve Şeffaflık: Vatandaşlara ulusal ve yerel kamu kuruluşlarının nasıl çalıştığı, maliyetleri ve kimlerin işbaşında olduğu hakkında bilgi verilmelidir.

- Telafi: Eğer taahhüt edilen standartta hizmet sunulmadıysa, vatandaştan özür dilenmeli, durum ayrıntılarıyla açıklanmalı, hızlı ve etkin bir şekilde sorun çözümlenmelidir. Ayrıca, vatandaşın şikâyeti karşısında, sempatik ve pozitif bir tutumla yaklaşılmalıdır.

- Paranın Karşılığı: Kamusal hizmetler vatandaşların parasının karşılığını tam anlamıyla verecek șekilde etkin ve tutumlu bir biçimde sunulmalıdır.

$\mathrm{Bu}$ konuda çalışmalar yapan Saygılığlu ve Arı da kamu hizmetlerinde vatandaş odaklı yaklaşımın oluşturulmasında kullanılabilecek temel göstergeleri şöyle siralamıştır (Saygılıoğlu ve Arı, 2003):

- Belli bir hizmet alabilmek için aşılması gerekli idari birim sayısı ya da kamu kurumlarına kolay erişebilme düzeyi,

- Talep edilen belli bir kamusal hizmet için geçen bekleme süresi,

- Kamusal hizmetlerin ve birimlerin ikame esnekliği; bir başka ifadeyle, düzeyinden ya da erişme niteliğinden memnun olmayan vatandaşların ya da iş çevrelerinin, bir hizmeti belli bir kamu kurumundan almak yerine, başka bir kamu kurumuna gitme olanağının derecesi; ya da bir hizmeti (tek birim yerine) değişik yerlerden alabilme hakkının tanınma derecesi, 


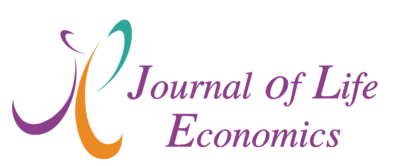

- Bir hizmetin tasarımından sunumuna kadar geçen süreçlerde, vatandaşların kamu kurumlarına gitmeden, elektronik olarak erişme ve işlemlerini bilişim teknolojileri aracılığıyla görme derecesi.

Vatandaş odaklı bu yeni anlayışla, devletin yönetim kalitesinin arttırılması, hesap verme mekanizmalarının güçlendirilmesi, kamusal hizmetlerin sunumunda saydamlık sağlanması, özel sektörü ve sivil toplum kuruluşlarını da içerecek biçimde vatandaşın hem politika oluşturmada, hem de uygulamada katılımının artırılması, devlete duyulan güvenin ve idarenin saygınlığının geliştirilmesi, hizmetin kalitesinin iyileştirilmesi gibi konular öncelikli hale gelmiştir. $\mathrm{Bu}$ bağlamda, vatandaş odaklı kamu hizmeti anlayışı, etkin bir devletin tesisinde bir zorunluluk olarak görülmeye başlamıştır (Saygılıoğlu ve Arı, 2003). Bu bağlamda, vatandaş odaklı kamu hizmeti anlayışıyla hizmetlerin "yanlış kapı yok" anlayışıyla mekândan, kurumdan ve programdan bağımsız olarak sunulması, "herkese tek tip" anlayışı terk edilerek vatandaşın öncelikleri, farklılıkları ve sıkıntılarının göz önüne alınması, kaynakların bu yönde tahsis edip etkinliğin sağlanması ile hizmet sunumunda işbirliğinin (kamu, özel sektör, STK ve vatandaş) oluşturulması esas hale gelmiştir (Duggan, 2010).

Sonuç olarak, değişen dünyada kamu hizmeti ve kamu yönetimi de artık değişmektedir. Hem gelişmiş hem de gelişmekte olan ülkelerde kabul görmeye başlayan vatandaş odaklı yaklaşımın bundan böyle kamu yönetimlerini hizmetin sunumundan denetimine kadar her aşamada etkili olacağı anlaşılmaktadır. Bu bağlamda, vatandaş odaklı anlayışla kamu yönetimlerinin ve kamu hizmetlerinin aldıkları şekil değişmektedir.İlk olarak, yeni hizmet anlayışıyla beraber vatandaşların memnuniyet düzeyleri ölçülmekte, talepleri öğrenilmekte ve öncelikli gördükleri alanlar tespit edilerek hizmetlerin iyileştirilmesinde göz önüne alınmaktadır. Bu bağlamda, vatandaşlara anketler uygulanmakta, mülakatlar yapılarak birebir iletişim sağlanmakta, e-mail adresleri, ücretsiz telefonlar, dilek, tavsiye ve şikâyet kutuları oluşturularak (Osborne ve Gaebler, 1992), vatandaşların şikâyet ve taleplerini iletmesi sağlanmakta ve bu şikâyet ve talepler düzenli olarak değerlendirilip gerekli önlemler alınmaya çalışılmaktadır. Ayrıca, yerel yönetimler vatandaşlara hizmet garantisi sağlayan, onların gündelik problemlerini takip eden ve bu problemlere çözüm üretmeye çalışan vatandaş büroları ve şikâyet hatları kurmaktadır (Çukurçayır, 2009). İkinci olarak, vatandaşların ihtiyaçlarını karşılamak için tüm kurumların işbirliği içinde çalışmasına başlanmıştır. Kurumlar hem birbirinden hem de gerektiğinde özel sektör kuruluşlarından iyi uygulamaları örnek almaktadır. Bu bağlamda, kurumlar, vatandaşların, özel sektörün ve sivil toplum örgütlerinin de katılımını sağlayarak, kamu yararını göz ardı etmeden, vatandaş odaklı yaklaşımın unsurları çerçevesinde, kamusal hizmetlerini koordineli, daha etkili ve kaliteli olarak sunma gayreti içerisine girmişlerdir (Uysal Şahin, 2014). Üçüncü olarak, hizmetlerin vatandaş odaklı yönde iyileştirilmesi için kamu görevlileri bu yönde eğitilmekte, gerekli imkân ve teçhizat sağlanmaktadır. İyi bir yönetim için, iyi yetişmiş ve gerekli donanıma sahip memurlar, kurumlar arası iyi iletişim ve yeniliklere açık olma yaşamsal öneme sahiptir. Aksi takdirde vatandaşların beklediği, kapsayıcı ve kaliteli kamusal hizmetten bahsetmek mümkün değildir (World-Class Public Services: Engaging Citizens and Staff, 2017).

Bilgi ve iletişim teknolojileri, hizmetlerin planlanmasından denetimine kadar her aşamada kullanılmaktadır. Diğer bir ifadeyle, internet ya da çağrı merkezleri gibi teknoloji avantajlarından yararlanılarak, hizmetler iyileştirilmektedir. Artık birçok hizmet internet üzerinden de verilebilmekte ve kamusal hizmetlere kolayca erişilebilmektedir. Bu şekilde bürokratik prosedürler azaltılmaktadır (Uysal Şahin, 2014).Birçok hizmet alanında tek pencereden/tek duraktan erişim giderek daha çok gerçekleştirilmeye başlamıştır. Vatandaşların, ihtiyaç duydukları hizmetleri hangi kurumun sunduğunu öğrenmesine gerek kalmadan ve istediğgi kanaldan kolayca ulaşabilmesi için çalışmalar yapılmaktadır. Tüm 


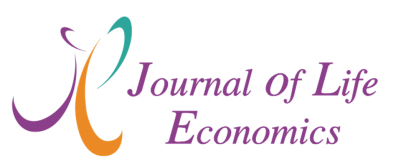

hizmet kanalları birlikte çalışacak şekilde entegre edilmektedir. Vatandaşların evden, işten, internet ya da telefon aracılığıyla işlerini halledebilmeleri amaçlanmaktadır (Uysal Şahin, 2014). Vatandaş odaklı bütçeler, vatandaş sözleşmeleri, yönetişim ve ombudsmanlık gibi kurumlar hayata geçirilmektedir. Çünkü bunlar vatandaş odaklılığı mümkün kılan araçlardır (Uysal Şahin, 2014). Son olarak, sürekli bir iyileşme ve modernizasyon için kurumların performans ölçümleri yapılarak raporlanmakta ve hesap verebilirlik oluşturulmaktadır (Canadian Centre for Management Development, 1999). Bu bağlamda, kamu kurum ve kuruluşları, sunulan hizmetlere yönelik hizmet standartları belirlemekte, çeşitli ölçüm yöntemleri aracılığıyla da vatandaşlar için önemli noktalar, vatandaşların hizmetlerden memnuniyeti ve hizmetler konusundaki şikâyetleri öğrenilmeye çalışılmaktadır. Böylelikle hizmeti başarısız kılan tüm olası sebepler hakkında bilgi sahibi olunmaktadır. Bu doğrultuda gerekirse, farklı gruplara farklı tip hizmet sunacak birimler için hizmet standartları belirlenmektedir (Karataş, 2007). Bu şekilde kamu hizmetlerinin yeniden tasarımına, süreçlerin standart hale gelmesine, hizmetlerin tüm vatandaşlara aynı kalite ve sürede sunulmasına imkân sağlanmaktadır. Talep edilen hizmetin hangi aşamada olduğu izlenebilmekte ve gerektiğinde vatandaşlar bilgilendirilerek hizmet sunumunda şeffaflık sağlanmaktadır (DPT, 2006).

Söz konusu düzenlemeler önemli gelişmeler olsa da tam anlamıyla yeterli değildir. Daha atılması gereken çok sayıda adım vardır. Örneğin, hizmetler konusundaki rahatsızlıkların bildirilip yeniden dizayn edilmesini sağlamak için vatandaşların yer aldığı konseyler kurulmalıdır. Ayrıca, vatandaş odaklı hizmet sunma anlayışına sahip kamu kurum ve kuruluşları, kamu hizmetlerinin sürekli gelişimini sağlamak için sistematik olarak kamu hizmetlerini iyileştirmeye ve bunların kalitesini, verimliliğini ve etkililiğini artırmaya yönelik çalışmalar yapmalı, hizmetler üzerinde sürekli gelişimi teşvik edecek yöntem ve süreçlerin gerçekleştirilmesini sağlamalıdır (Karataş, 2007). Bu kapsamda yapılanlar sadece kamu hizmetinin sunumuyla sınırlandırılmamalı, sunulan hizmetlerin denetimi de yine vatandaş odaklı bir perspektifle gerçekleştirilmelidir. Böyle bir denetim kamu hizmetlerinin ne kadar vatandaş odaklı olduğunu sorgularken bunu da vatandaşı sürece dahil ederek ve görüş, talep ve beklentilerini dikkate alarak gerçekleştirmelidir.

\section{ROL ̈̈}

4. VATANDAŞ ODAKLI HIZMETİ YAKLAŞIMINDA SOSYAL MEDYANIN

Geleneksel bürokrasiye yönelik eleştirilerin ve özel sektör yönetim modellerine olan artan ilginin öne çıkarttığı YKY yaklaşımı, kamu sektöründe tam bir dönüşümü başlatırken, bu dönüşüm de vatandaşı, daha çok merkeze alan bir anlayışı beraberinde getirmiştir. Vatandaşların istek, beklenti ve ihtiyaçların daha hızlı, etkin bir şekilde karşılandığı; daha şeffaf, hesap verebilir ve katılımcı yapı üzerine kurulan vatandaş odaklı kamu hizmeti yaklaşımı hayata geçirilmeye çalışılmaktadır. Bu bağlamda, hizmet stratejilerinin de, vatandaşların taleplerini en iyi şekilde karşılayacak modern, yaratıcı ve innovatif olmasına dikkat edilmeye başlanmıştır. İşte bu noktada, web tabanlı yeni medya teknolojileri bir fırsat yaratmıştır. Web 2.0 teknolojileri ve bu teknolojilerinin yansıması olan sosyal medya araçları, vatandaş odaklı hizmet anlayışının hayata geçirilmesinde hükümetlerin önemli politika araçlarından biri olmuşlardır.

Kamu sektöründe sosyal medya araçlarının kullanımı oldukça yeni sayılır. Daha çok Batı ülkeleri bir politik strateji oluşturarak bu araçları etkin bir şekilde değerlendirmektedir. Ama, son yıllarda, diğer ülkelerin de giderek bu araçlara başvurduğu görülmektedir.Şu bir gerçektir ki, sosyal medya araçlarının kamu sektöründe giderek daha çok yer bulması, kamu hizmetlerinin sunumu ve yönetiminde önemli bir paradigma değişikliğine yol açmaktadır. 


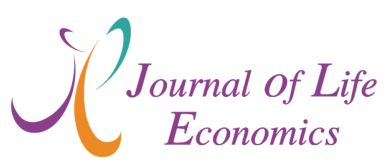

Kamu kurumları interneti önceleri sadece bir duyuru veya bir bülten olarak kullanırken; şuanda Web 2.0 ve beraberinde gelen sosyal medya araçları hükümetlerin yönetim tarzı, vatandaşla iletişim kurma biçimi ve taleplere yanıt verebilme olanaklarını oldukça değiştirmektedir. Hatta bu değişim devletin de, "Devlet 2.0" olarak anılmasına yol açmaktadır (Ressler, 2009).

Sosyal medya devletler tarafından biri dizi amaç için kullanılabilmektedir. Temelde dört nedenden ötürü devletin sosyal medyayı kullanıldığı iddia edilmektedir. $\mathrm{Bu}$ nedenler şöyle sıralanır (Stem and Ibarra, 2011):

- Finansal zorlukların, kuruluşları maliyetleri azaltmaya, hizmet sunum verimliliklerini geliştirmeye ve mevcut kaynakları optimize etmeye zorlaması,

- Birden fazla erişim kanalıyla, vatandaşların kamu sektörüyle etkileşim kurma yönünde daha fazla seçim yapmalarını sağlaması

- Şeffaflığı, hesap verebilirliği ve uyumu geliştirici yönde, vatandaşlara olanaklar sağlanabilmesi

- Ölçülebilir sonuçlara elde etmede yeni teknolojilerin birçok avantaj sunmasıdır.

Yukarıda sayılan yanında, bilginin yayılması, farklı devlet organları arasında bilgi paylaşımı ve işe alımlar sırasında vatandaşa ve diğer kullanıcılara ulaşma da devleti sosyal medya kullanımına iten nedenlerin başında gelmektedir (Chun et al., 2010). Ama belki de en önemlisi vatandaşların politika yapma ve karar verme süreçlerine daha çok katılımını sağlama, yani katılımcılığı arttırmadır. Ayrıca, kamu sektörü, yeni programlar ve hizmetler geliştirmek, reklam kampanyalarını yaymak, faaliyetlerini genişletmek ve vatandaşların günlük sorunlarını çözmede onlarla etkileşimli diyaloglar kurarak vatandaşları devlete daha erişilebilir kılmak için sosyal medyayı kullanmaya başlamıştır (Falco, 2011).

Sosyal medya, devletin vatandaşlarla birlikte çalışmasına, yani karşılıklı etkileşimde bulunmasına olanak vererek hizmetlerin kalitesini, hizmetlere erişimi ve verimliliği arttırmada önemli bir rol oynamaktadır. Bu bağlamda, vatandaşların da kamu hizmetlerinin gerçekleştirilmesindeki rolleri değişime uğramış, "ortak üretim/yapım (co-production)" anlayışının egemen olmaya başlamasıyla vatandaşlar kamu hizmetlerinin oluşumundaki aktörlerden biri olmuşlardır. Vatandaşın rolünde sosyal medyayla birlikte meydana gelen bu değişim YKY'nin vatandaşa özel sektördeki müşteri mantığıyla yaklaşımına ters düşer hale gelmektedir. Çünkü YKY'de vatandaşlar kamu hizmetlerinin üretiminde "ortak" olmaktan çok "müşteri”" konumunda iken; bilgi ve iletişim teknolojilerinde gelinen son nokta ve özellikle sosyal medyanın sunduklarıyla vatandaşların "aktif katılımı" öne çıkmaya başlamıştır. Web 2.0 ve sosyal medyanın gelişimi, geleneksel vatandaş-devlet ilişkilerine bağlı olarak ortaya çıkan düzenlemeleri değiştirmiş, vatandaşın devletle birlikte ortak üretimini destekleyen ve geliştiren bir ortam sağlamıştır.

Linders (2012), sosyal medya çağında, vatandaşla hükümet arasındaki etkileşime ve vatandaşların kamu hizmetlerin ortak üretiminde aldıkları role bağlı olarak 3 tip ortak üretim/yapımdan bahsetmiştir. Bunlar: Vatandaş Kaynaklı (Citizen Sourcing), Platform olarak Hükümet (Government as a Platform) ve Kendin Devlet gibi Yap (Do it Yourself Government). Bunların yanında bir dördüncü olarak da Bürokratik Model (Bureaucratic Model) eklenmektedir. Bu model kamu kurumları arasındaki etkileşimi kolaylaştıran ve Web 2.0 teknolojileri çerçevesinde kamu hizmetlerinin sunumunda yerel yönetimlere belirleyici rol veren bir yapı sunmaktadır: 


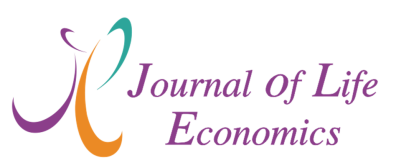

- Vatandaş Kaynaklı (Citizen Sourcing (G2C)) olarak adlandırılan modelde vatandaşlar devletle olan ilişkilerini güçlendirecek ve iki taraf arasındaki konvansiyonel gerginliği giderebilecek katılımcı bir çerçevede kamu sektörü sunumunu gerçekleştirmede hükümete yardımcı olurlar. Vatandaşlar hükümetle fikirlerini paylaşırlar. Bunu da genellikle sosyal medya kanalları aracılığıyla geri bildirim sağlayarak politik kararların hazırlanıp alınmasına müdahil olma şeklinde yaparlar. Devlet de onlara bu fırsatı sağlar. Bu nedenle, vatandaş kaynaklı yaklaşım, sivil öğrenmeye elverişlidir ve devletin bakış açısını, vatandaşların hükümet programlarının ve hizmetlerinin "kullanıcıları ve seçicileri" olmaktan politika ve kararların "üreticilerine ve şekillendiricileri” olmaları yönünde değiştirir.

- Platform olarak Hükümet çerçevesinde, devlet vatandaşları, kamu hizmetlerini kendileri geliştirmeye teşvik etmek için bilgi dağıtımı ve kıyaslama analizlerinin kullanılması yoluyla kamu hizmetlerinin tasarımı ve yaratılması konusunda aktif bir şekilde işbirliği yapmaya çağırmaktadır. $\mathrm{Bu}$ nedenle, devlet misyonunu yerine getirmek için sosyal medya kanalları vatandaşlarla etkileşimi artırmak veya yenilikçi fikirler üzerine hükümet paydaşları ile işbirliği içinde çalışmak için kullanılabilir $\mathrm{Bu}$ senaryoya göre, hükümet sonuçta ortaya çıkan etkinlikten sorumlu değildir, ancak platformunu ve nüfuz alanını kamusal değeri daha fazla arttırıcı yönde geliştirebilir.

- Son olarak Kendin Devlet Gibi Yap modelinde, vatandaşlar hükümetten çok az veya hiç etkilenmeden kendilerini yönetirler. Bu bağlamda, çevrimiçi müşteri geribildirim mekanizmaları, yukarıdan-aşağı yönetim tarzı, merkezi denetimler gibi uygulamaların yerini almaya başlarken, vatandaşlar sosyal medya uygulamaları aracılığıyla birbirleriyle bağlantı içine girmektedirler. Bu çerçevede, topluluklar hem deneyim ve bilgi alışverişi hem de diğer paylaşım mekanizmaları aracılığıyla hükümet odaklı kamu hizmeti sunumuna önemli bir katkı sunarlar. Hizmetlerin tasarımı ve gerçekleştirilmesinde belirleyici olurlar.

- Linders tarafindan tanımlanan kategorilere ek olarak, Bürokratik model (G2G) de dikkate alınmalıdır. Bürokratik yönetim modeli uyarınca, genellikle Web 2.0 teknolojilerinin kullanımını denetlemek için bir düzenleyici çerçeve oluşturulur ve yerel yönetimler, kamu hizmetleri sunmak için Web 2.0 teknolojilerinin uygulanmasında ve yönetiminde öncü rol oynamaktadır. Hükümet, Web 2.0 teknolojilerinin kullanımı için strateji tasarlar ve iletişim ağını doğrudan yönetir. Vatandaşların özel istek ve özelliklerinin daha az dikkate alındığı bu model hükümet denetimine dayanır ve bu nedenle vatandaşlar kamu hizmetleri üzerinde daha az kontrole sahiptir. Kamu hizmetlerini Bürokratik Modele göre yöneten hükümetler, Web 2.0 teknolojilerini ancak şeffaflığı arttırmak amacıyla kullanmaktadırlar; bu şeffaflık, sosyal medya siteleri yoluyla hükümet bilgisinin iletimi olarak yorumlanmalıdır. Özetle, Web 2.0 çağında, kamu idarelerinin tek bir yönetişim modeli mevcut değildir ve kamu idaresine "en uygun" model yoktur. Her modelin uygunluğu, hükümetlerin Web 2.0 teknolojilerinin uygulanmasında oynayacaklarına inandıkları role bağlı olacaktır.

Richards (2010) ise teknoloji ve sosyal medya sitelerinin kullanımının gelişmesine bağlı olarak yeni bir vatandaşlık türü meydana geldiğinden bahsetmiştir. Teknolojinin bu şekilde kullanılmasıyla "dijital vatandaşlık" olarak adlandırılan vatandaşlık anlayışı gelişmeye başlamıştır. Bu vatandaşlık da kendi içinde 3'e ayrılmaktadır. İlk tür dijital vatandaşlık, iletişim kurmak ve gerçek zamanlı bilgiye erişmek için kağıt postalar yerine elektronik posta kullanan ve devletin sosyal medya sitelerindeki görünümünden faydalanan kişisel sorumluluğa dayanan bir sayısal vatandaşlıktır. İkinci tür, çevrimiçi tartışma forumlarından 


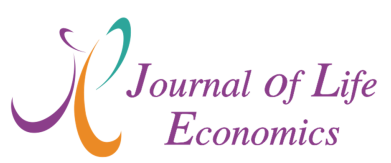

sosyal medya siteleri aracılığıyla faydalanan, geri bildirim, yasalara itaat ve diğer birçok etkinliği organize eden katılımcı bir sayısal vatandaşlıktır. Üçüncü tür vatandaşlık ise, sosyal medya siteleri aracılığıyla kamuoyunun sorunların konuşulduğu çevrimiçi tartışmalara katılmayı tercih eden adalet odaklı sayısal bir vatandaşlıktır.

Tüm bu vatandaşlık tartışmaları göstermiştir ki, artık vatandaşlar, teknolojik ilerlemeler ve sosyal medya araçlarının etkisiyle eski geleneksel anlayışla hareket etmesi mümkün değildir. Daha aktif, katılımc1, sorgulayan ve belirleyen bir rol oynamaktadırlar. Onlardaki bu değişim ise devletin rolünde de değişimi mecbur kılmaktadır. Gittikçe dijitalleşen devlet yapısıyla beraber üç unsur öne çıkmaya başlamıştır. Bunlar: e-yönetişim, edemokrasi ve e-devlettir. Vatandaş odaklı kamu hizmeti anlayışı için önem taşıyan bu unsurlardan e-yönetişimle, yeni bilgi ve iletişim teknolojilerinin hükümetin yönetim ve organizasyon yapılarına entegre edilerek verimli iç dinamiklere sahip olunduğu görülmektedir. E-demokrasi, katılımcı demokrasi anlayışını geliştirirken e-oylama ve ekatılımı kavramları da dijitalleşmenin sağladığı olanaklarla öne çıkmaya başlar. E-devlet, ise hükümetlerin ve vatandaşların içeriği ortak üretebilmelerini mümkün kılan, böylece kamu politikalarının oluşturulması ve uygulanması konusunda gerçek işbirliğine olanak tanıyan çok kanallı bir hizmet mimarisi oluşturur (Deschamps, McNutt and Zhu, 2012). Bütün bu gelişmelerin yanında, özellikle yeni sosyal medya araçları ile birlikte dijital yönetişime geçilmesi yeni bir devlet yönetim anlayışının oluşturulmasında önemli bir aşama olmuştur.Geleneksel yönetim anlayışı, ikinci nesil web teknolojilerinin gelişimiyle birlikte giderek ortadan kalmaktadır. Bu yüzden, devlet ve vatandaşların kamu hizmetlerini ağ üzerinden ortak üretimine odaklanılmaktadır (Meijer, 2011).Hizmet planlaması ve yönetimi konularındaki geleneksel kavramlar artık güncelliğini yitirmiş durumdadır. Hükümetler, vatandaş odaklı hizmeti güçlendirmek ve hatta biraz da dönüştürerek, ortak/birlikte üretim anlayışını yerleştirmek için sosyal medyaya daha çok başvurmaktadır.

Literatüde, kamu sektöründe sosyal medya kullanımını ifade etmek için farklı kavramlardan yararlanılmaktadır. Bunlardan bazıları: Devlet 2.0 (Government 2.0), Devlet gibi Kendin Yap (Do-it-yourself Government), İşbirlikçi Yönetim (Collaborative Government), Açık Devlet (Open Government), Biz-Devlet (We-Government)'tir (Khan, Swar and Lee, 2014). Kamu hizmetlerini vatandaşın ayağına getiren sosyal medya, sunduğu etkileşimli iletişim ortamları ve anında tepkiyi iletebilmesiyle vatandaşın aktif katılımını artırmakta, bu sayede kamu idarelerini de daha demokratik ve yönetişim ilkeleri 1şı̆̆ında hizmet sunan bir yapıya sokmaktadır. Sosyal medya araçları hızlı, kolay ve masrafsız bir iletişim yöntemi olma özelliği ile kamu kurum ve kuruluşları tarafından halka bilgi ve hizmet sunumunda giderek tercih edilmeye başlamıştır. Sosyal medya araçlarını kullanarak katılım, şeffaflık ve hesap verebilirliği güçlendirmeyi hedefleyen merkezi ve yerel yönetim kuruluşlarının bu araçlardan verimli olarak yararlanmaları ise ancak doğru bir sosyal medya yönetimi ile sağlanabilir (Erkek, 2016).

Her düzey kamu kurumunda web sitelerine artık, Facebook, Twitter veya YouTube düğmeleri eklenmektedir. Bununla beraber, sosyal medyanın kamu sektöründe ne kadar başarılı ve yararlı olduğu; kurumların kendi sosyal medya stratejilerini nasıl tasarlayabileceği gibi konular tam manasıyla netleşmiş değildir. Kamu kurumlarına ait web sayfalarının interaktif ve kolay kullanılması, hızlı ve seri bir şekilde sosyal medya uygulamalarına ulaşılması gerekmektedir. Hizmetler hakkında gerekli bilgilendirmeyi ve erişimi sağlamak için bu oldukça önemlidir. Aksi halde kamu kurumları için sosyal medya bir külfet haline gelebilir. O yüzden mevcut yapının artı ve eksileri dikkate alınarak bir yol haritası çıkartılmalıdır. 


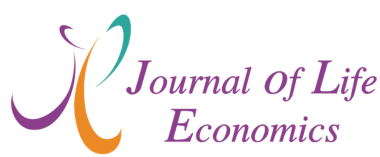

\subsection{Vatandaş Odaklı Kamu Hizmeti Yaklaşımı Açısından Sosyal Medyanın Avantajları ve Dezavantajları}

Devletler, hizmetleri iyileştirme, vatandaşlarla olan iletişim ve etkileşime yardımcı olma, vatandaşın katılımını arttırma, bilgi alışverişini kolaylaştırma ve yönetişim düzeyini geliştirme gibi çeşitli avantajlardan dolayı sosyal medyayı giderek kullanmaya başlamışlardır (Al-Badi, 2014).Sosyal medya, devlet-vatandaş ilişkilerini yeniden şekillendirirken; kamu kurumları arasındaki en iyi uygulamaların transferine yardımcı olabilecek güçlü bir araç olma yolunda ilerlemektedir. Bertot vd (2010b), sosyal medyanın kamu kurumları için 3 temel yarar sunacağından bahsetmiştir. İlk olarak, demokratik katılımı arttırma potansiyeldir. Halkı yönetim süreçlerine katmak için sosyal medya teknolojilerini kullanma, katılımcı diyalogu/yapıyı güçlendirirken; politika geliştirme ve uygulama tartışmalarında vatandaşa konuşabileceği ve fikirlerini ifade edebileceği bir alan sunmaktadır. İkinci olarak, ortak üretim/yapımı mümkün kılmasıdır. Hizmet kalitesini, sunumunu ve yanıt verebilirliği iyileştirmek için sosyal medya, vatandaşın ve devletin kamu hizmetlerini birlikte geliştirme, tasarlama ve sunma imkanı sağlamaktadır. Son olarak, ortak çözümler ve innovasyon sağlamasıdır: Büyük ölçekli sosyal sorunlara yönelik innovatif çözümler geliştirmek için kamusal bilgi ve tecrübeye dayalı yenilik arayışında çözümler ve yenilikler sunar. Kitlesel kaynak sağlamayı kolaylaştırmak için devlet, verileri ve diğer girdileri sosyal medya aracılığıyla paylaşılarak halkın yenilik yapması için bir temel oluşturulmaktadır.

Vatandaşların, hükümetlerin sosyal medyayı benimsemesinden sağlayacağı faydaların başında: sosyal medya vasıtasıyla, pasif rollerini bırakıp hükümetle etkileşime girebilecek hele gelerek aktif bir role kavuşmaları gelir. Web 2.0 araçlarını kullanarak vatandaşlar siyasetçilere ulaşabilir ve internet üzerinden görüşlerini çok daha rahat bir biçimde paylaşabilirler. Politika tasarımı ve uygulamasından hizmet sunumuna kadar her alanda belirleyici bir role sahip olurlar. Bu doğrultuda sosyal medyanın genel olarak sağladığ faydalar şöyle ifade edilebilir (COI, 2011):

- Devlet iletişiminde iyileşme sağlayarak vatandaşların devlet erişiminde artış,

- Minimum maliyetle daha geniş kitlelere (vatandaşlar ve ikamet) hizmet etme olanağı.

- Hükümetlerin, vatandaşlar, ortaklar ve paydaşlarla olan ilişkilerinde daha verimli ve üretken olabilmesi.

- Gerektiğinde haberleşmeleri hızla ayarlamak veya değiştirmek için daha fazla bir alan sunmasi.

- İletişimin uzun vadeli maliyet etkililiğinde bir iyileşme.

- Kamusal geri bildirim ve girdi hızında bir artış.

- Belli konularda belirli kitlere ulaşma yeteneğine sahip olma.

- Geleneksel medya kanallarına hükümet bağımlılığının azaltılması ve yanlış medya bilgilendirmesine karşı mücadele.

Tüm bunlardan anlaşıldığı üzere devletin sosyal medya kullanımının sağladığı faydalar arasında etkinlik, kullanıcı kolaylığı, şeffaflık, hesap verebilirlik, vatandaşların katılımını arttırma, gelişmiş güven ve demokrasi bulunmaktadır. Sosyal medya uygulamalarını kullanarak, hükümetler geleneksel iletişim yöntemlerini kullandığında veya kendi sosyal sitelerini geliştirdiğindekine göre daha fazla şekilde insanlarla verimli iletişim kurabilir ve paradan ve kaynaklardan tasarruf edebilir. Kullanıcı kolaylığı, sosyal medyanın bir parçasıdır çünkü kullanıcılar, devlet tarafından sağlanan bilgileri almak isteyebilir. Vatandaşlara hükümetlerin yaptıklarını bildirmek, şeffaflığı ve hesap verebilirliği teşvik edebilir. Sosyal medya, vatandaş katılımını, örneğin hizmetler ve içerikleri hakkındaki geribildirim açısından katılım ve işbirliği yapma fırsatlarını arttırarak geliştirmektedir. 


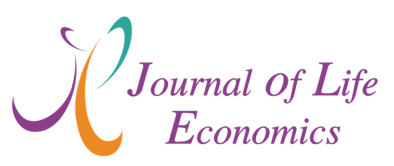

Vatandaşların bu süreçlere dahil olması, demokratikleşmeyi ve vatandaşların hükümete olan güveni artırabilir (Picazo-Vela et al, 2012). Bütün bu faydalar ise vatandaş odaklı kamu hizmeti anlayışına ulaşılmasına katkı verir. Çünkü şeffaflık ve hesap verebilirlikten tutun da erişim ve katılımda sağlanan artış ve iyileşmeler söz konusu anlayışa hizmet etmekte ve hatta bu anlayışı dönüştürmektedir. Özellikle sosyal medyayla birlikte hizmet tasarımı ve sunumunda vatandaşla ortak üretimin/yapımın olanaklı hale gelmesi vatandaş odaklı hizmet anlayışında vatandaşa atfedilen hizmetlerin alıcısı olma rolünün hizmetlerin üreticisi/yapıcısı olma yönünde değiştirmektedir.

Sosyal medyanın kamu sektöründe birçok faydası olmasına rağmen, bazı risklere de sahiptir. Örneğin, sosyal medya etkileşim, gizlilik, güvenlik, veri yönetimi, erişilebilirlik, toplumsal kapsayıcılık ve yönetişim konularında bir takım sıkıntılar yaratmaktadır (Bertot, Jaeger and Hansen, 2012). Bazı bilim adamları, sosyal medya araçlarının etkisiz olduğuna, vatandaşları siyasi tartışmalara dahil etme konusunda çok az şey sağladıklarına (Baumgartner and Morris, 2010), demokratikleşmeye çok zarar verdiğine inanmaktadırlar (Shirky, 2011). Başka akademisyenler ise, sosyal medyayı sınırsız bir bölge olarak görmekte ve hükümetlerin sosyal medyayı uygulama konusundaki deneyim ve bilgi eksikliklerine işaret etmektedirler (Lee and Kwak, 2012). Şeffaflığın aşırı olması nedeniyle kontrol kaybının yaşanması, kullanıcılar tarafından düşük düzeyde katılım veya zarar verici tutumlar, vatandaş merkezli kültür eksikliği ve iletişim tarzlarıyla ilgili riskler de sosyal medyanın devlet tarafından kullanımında karşılaşılabilecek sıkıntılardır.

Sosyal medya uygulamasında, hükümetlerin iki seçeneği vardır: platform geliştirmek veya Facebook veya Twitter gibi bir sağlayıcı kullanmak. Hükümetler platform geliştirirse, toplanan ve depolanan bilgileri kontrol etmekle sorumludurlar. Bununla birlikte, eğer bir üçüncü taraf sağlayıcı kullanırsa, bilgilerin sahibi net değildir ve hükümetin bu bilgiler üzerinde sinırlı kontrolü olabilir (Bryer and Zavattaro, 2011). Bununla beraber, sosyal medya uygulamalarında ortaya çıkabilecek en büyük risk aslında güvenlikle ilgilidir. Sosyal medya iki yönlü iletişim içerdiğine sahip olduğundan kamu kurumlarının web sitelerine kötü amaçlı yazılım sızma riski mevcuttur (Bertot, Jaeger and Hansen, 2012). Bu nedenle BT uzmanları hükümetin bilgi teknolojisi altyapısını korumaya hazır olmalıdırlar. Son olarak, yönetime özel koşullar, diğer risk türlerine neden olabilir. Sosyal medyayı uygulamak isteyen hükümetler, medyayı güncellemede sorumlu olanların yeni iletişim kanalını güncelleme yeteneği ve zamanının olup olmayacağını kontrol edip ona göre gerekli önlemleri almalıdırlar (PicazoVela et al, 2012).

Tüm bunların yanında, nüfusun dijital okuryazarlık düzeyi ve derecesinin yetersiz olması, bilgi yönetimi ve siber güvenliğe ilişkin riskler, yeterli mali kaynak, insan kaynağı ve lojistik kaynağın olmaması, sosyal medyanın rolü ve önemine ilişkin özellikle yönetim düzeyinde yeterli farkındalığın oluşmaması, belirli bir politika veya yol haritasının olmaması, vatandaşlardan negatif geri bildirimler alma korkusu gibi riskler de sosyal medyanın kamu sektörünce adaptasyonunda karşılaşılabilecek risklerdir.

\subsection{Vatandaş Odaklı Kamu Hizmeti Yaklaşımı için Sosyal Medya Stratejisi}

Devletler, sosyal medya sitelerini nasıl yönetebilecekleri ve bu kanalın etkin bir şekilde nasıl kullanılabileceği konusunda dikkatle düşünmelidirler. Sosyal medya sitelerini yönetme, farklı yaklaşımlar kullanarak yapılabilir; işletmeler tarafından sosyal medyayı yönetmede kullanılan yaklaşım bu konuda iyi bir örnektir. "Dört R" yaklaşımı olarak ifade edilen bu yaklaşım dört ana eylemi temel alır: ilki "Gözden Geçirme (Review)" dir. İnsanların çevrimiçi olarak söylediklerini bilme ve izleme üzerine odaklanılarak gözden geçirilmelidir. İkincisi, "Cevap Verme (Respond)" dir. Söz konusu sosyal medya kanalının 


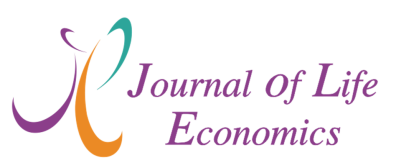

aktif bir iletişim kanalı olduğundan emin olmak için cevap verme boyutu test edilmelidir. Üçüncüsü "kaydetme (Record)" dir. Zengin ve yüksek kaliteli içeriği kaydetmek gerekmektedir. Sonuncusu ise "Yeniden Yönlendirme (Redirect)"dir. İnsanları, benzer sorunları yaşayan başkalarına yönlendirerek aynı durumda olanların faydalanması sağlanabilir. Dolayısıyla hükümetler sosyal medya sitelerinden olabildiğince fazla fayda sağlamak için bu tür yaklaşımlardan etkili ve kolay bir şekilde nasıl yararlanabilecekleri üzerine düşünmelidirler (Sandsmark, 2011). Özellikle hükümetler, yalnızca dinlemek ya da izlemekle kalmayıp aynı zamanda vatandaşlara aktif kanal sağlamak için sosyal medya kullanıyorlarsa, onlar için sosyal medya siteleri vazgeçilmez bir unsur haline gelmektedir. $\mathrm{O}$ yüzden hükümetler için doğru bir sosyal medya stratejisinin belirlenmesi dönüşüm yaşayan devlet anlayışı çerçevesinde bir gerekliliktir.

Vatandaş odaklı kamu hizmeti anlayışının kilit unsurları olan şeffaflık, katılım ve işbirliğini teşvik etmede belirleyici olan üç farklı sosyal medya kullanım stratejisi bulunmaktadır. Birinci strateji "itme (push)" stratejisidir. Sosyal medya uygulamaları, var olan (genellikle statik olan) internet varlığının bir uzantısı olarak kullanılır ve "mesaj almaya yarayan ek bir iletişim kanalı" olarak hizmet eder. Bu durum, denetlenmeyen Twitter güncellemeleri, herkese açık yorumları engellenen ve bu yüzden tercih edilmez hale gelen Facebook paylaşımları ve az takip edilen YouTube kanallarına yol açar. İkinci strateji, "çekme (pull)" stratejisi olarak adlandırılır. Sosyal medya uygulamaları, takipçileri, haberlerin toplu bulunduğu kurumun web sitesine yönlendirmek için kullanılır. Çekme stratejileri, bir miktar etkileşim sağlayarak kitlelerin aktif olmasına imkan verir ve bu da Facebook sayfalarındaki birkaç yorum, birkaç retweet (diğer Twitter kullanıcılarının mesajlarının yeniden kullanımı) ya da Twitter takipçilerinden gelen yanıtlara verilen cevapları kapsar. Örnekler, hükümetin salmonella salgını veya $\mathrm{H} 1 \mathrm{~N} 1$ grip kampanyası hakkında halk1 bilgilendirmek için sosyal medya araçlarını kullanmasını içermektedir. Üçüncü strateji "ağ oluşturma (networking)" stratejisidir. Sosyal medya araçlarının kullanımı, kurumlar ve vatandaşlar arasında ileri ve geri etkileşim şeklindedir. Sosyal medya yöneticileri genelde onları kimin takip ettiğini ve kimlerin ulaşmak istediklerini bilir. Facebook, Twitter vb. araçları yalnızca mesajları kontrol etmek ve yönlendirmek için değil aynı zamanda, kurumlarının misyonuyla alakalı olabilecek konuları takip etmek ve bazı işleri yerine getirmek için de kullanılır. Ayrıca, farklı içerik alanlarındaki sosyal medya araçları stratejik bilgi paylaşımı ve bilgi oluşturma aracı olarak da görülmektedir. İnsanlarla etkileşim içine girilerek yorumlara yanıt verme, bazı konuları tartışmaya açma ve online diyaloglar kurma mümkün hale gelir (Mergel, 2010).

Giderek üçüncü tür stratejinin kamu sektöründe öne çıktığı düşünüldügüünde politika ve uygulamaların bu yolda dönüşmeye başlaması beklenmektedir. Tabi, bu dönüşüm yaşanırken belirli konulara dikkat edilmesi gerekmektedir. Devlet hizmetlerinin sosyal medyanın kullanımı yoluyla dönüşmesinde başarıya ulaşmanın anahtarları, vatandaşları ve ilgili grupları tanıma (demografik, sosyal ağ oluşturma ve işbirliği biçimleri), sürekli olarak vatandaş memnuniyetini ölçme, yeni teknolojik eğilimleri anlama, hükümet genelinde en iyi uygulamaları paylaşma ve stratejik bir plandır. Stratejik planın geliştirilmesinde dikkate alınması gereken unsurlardan bazıları ise, kamu hizmeti beklentileri (sonuçlar, adalet, şeffaflık), sosyal medyanın stratejik odağı, mevcut BT yeteneklerinin ve ortaya çıkan teknolojilerin envanteri, sosyal medya yönetişimi (haklar, sorumluluklar ve kurallar), kilit performans göstergeleri (ölçümler), sosyal medya uygulama portföyü, proje sıralaması ve uygulama takvimidir (Dadashzadeh, 2010).

Kamu sektöründe sosyal medya tabanlı bir dönüşüm yaşanırken bunun her düzeyde, yani hem merkezi hem yerel yönetim düzeyinde gerçekleştirilmesi, bu bağlamda bir politika 


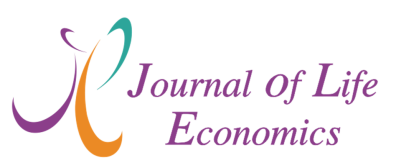

ve bir yol haritasının oluşturulması gereklidir. Ayrıca kamu idarelerinin bu siteleri aktif olarak kullanarak vatandaşın değişen istek ve ihtiyaçlarına yanıt veren içerikler üretmesi, onların erişimine sürekli açık olması gerekmektedir. Sosyal medyada doğru bir şekilde yer almak belirli bir uzmanlığı gerektirmekte, bu konuda kamu kurumlarının bir takım hazırlıklar yapmasını zorunlu kılmaktadır. Kamu kurumlarının bu konuda dikkat etmesi gereken bazı hususlar aşağıdaki gibi sıralanabilir (Erkek, 2016):

- Her kamu kurumunun etkili bir sosyal medya rehberi ve stratejisi bulunmalıdır. Bu strateji uzman bir ekip tarafından oluşturulmalı, hem görsel anlamda hem de içerik oluşturma konusunda tüm süreç uzman ekipler tarafından yönetilmelidir.

- Kamu çalışanları kurumun sosyal medyadaki varlığını kabul etmeli, bu konuda personele gerekli eğitimler verilmelidir.

- Kurum personeli sosyal medya ortamlarında kullandıkları dil ve paylaştıkları verilere özen göstermeli, görevlerinin gerektirdiği ciddiyet ve düzeyi söylem ve paylaşımlarında özenle korumalıdır.

- Etkili bir sosyal paylaşım ancak karşılıklı iletişimde edinilen geri dönüşümler ile sağlanacağından geri bildirim sisteminin doğru şekilde yönetilmesi esastır. Halkın yaptığı yorumların raporlanması, ilgili yöneticilere düzenli olarak iletilmesi, analizlerinin yapılması gerekmektedir.

- Sosyal medya araçları, sadece şu anda mevcut hizmetlere yönelik bir geribildirim kanalı olarak kalmamalı, farklı kamusal bilgi ve hizmetlerin yenilikçi yöntem ve teknolojilerle sunumuna imkân sağlayacak bir araç olarak kullanılabilmelidir.

- Güvenlik önlemleri en yüksek seviyede tutulmalı, özellikle takipçilerin ve çalışanların veri güvenliği sağlanmalı, takipçilerin de güveni kazanılmalıdır. Sosyal medya ortamlarında kurumsal ve kişisel verilerin gizlilik ve güvenliği ile ilgili kurallara mutlaka riayet edilmelidir.

Sosyal medya kanalları kamu kurumlarına pek çok imkanı sağlamaktadır. Örneğin, kamu kurumları haftalık yâda aylık basın bilgilendirmelerini bu kanallar üzerinden yapabilirler. Mevzuat değişiklikleri, yeni uygulamalar, etkinlikler ve projeler hakkında vatandaşlara bilgi verebilir. Vatandaşlardan bu konularla ilgili geri bildirimlerde bulunmalarını isteyebilirler. Seçim kampanyalarını yönetirken siyasiler sosyal medya araçlarını kullanabilmektedirler. Belirli konularda anket uygulamalarını bu kanallar aracılığıyla gerçekleştirebilir veya reklam amaçlı kullanabilirler. Bunun yanında, daha ileri bir noktada yerel yönetimler meclis toplantılarını bu platformlar üzerinden yayınlayabilir ve bu yayınlar için vatandaşın görüşlerini iletmesini sağlayacak blog kanalları oluşturabilirler. Böylece vatandaşlar süreçlere dâhil olma şansına sahip olur ve e- katılımcılık güçlendirilirken devlette daha fazla şeffaflık ve daha demokratik bir yönetim biçimi sağlanabilir.

Kamu kurumlarında sosyal medyanın etkin olarak kullanıldığı örneklere rastlanılmaktadır. Özellikle sosyal medya uygulamalarının doğduğu yer olan Amerika Birleşik Devletleri (ABD)'nde kamu kurum ve kuruluşları sosyal medyayı oldukça aktif şekilde kullanmaktadırlar. Başkan Obama döneminde Beyaz Saray'ın 2009 yılında yayınladığı "Beyaz Saray Açık Hükümet Direktifi" aracılığı ile daha "hesap verebilir" bir devlet için tüm devlet kurumlarının internet üzerinden (online) platformlarla halka bilgi aktarımında bulunması gerektiği belirtilmiştir. 2011 yılında ise ABD'de Devlet Hesap verebilirlik Ofisi tarafından devlet organlarına, sosyal medya üzerindeki gönderilerini yönetmek ve korumak adına politikalar ve bu politikaların uygulanması için prosedürler hazırlamaları konusunda direktifte bulunulmuştur (Mergel, 2012). 


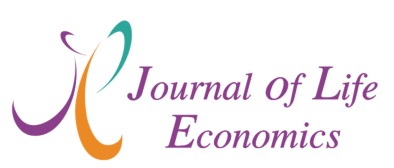

ABD'de birçok kamu kurumu YouTube üzerine kurumlarını ve verdikleri hizmetleri tanıtıcı videolar koyarak kendi YouTube kanallarını yapmışlardır. Sosyal medya araçları yoluyla kamu kurumları kendilerinden bilgi ve hizmet alan vatandaş kitleleri arasında vatandaştan vatandaşa (Citizen2Citizen) etkileşim kanalları kurmaktadırlar. Örneğin ABD'de Savaş Gazileri Kurumu (Veterans Administration), gazilerin sanal ortamda bir araya gelebilmes için Facebook, YouTube, Flickr ve Twitter üzerinde ağlar kurmuştur. ABD'de kamu kurumları vatandaşları bilgilendirmek, onların görüş ve şikâyetlerini almak üzere İnternet günlükleri (bloglar) yayımlamaktadırlar (Bertot et al., 2010a).

Kanada' da 2008 yılında, kamu görevlilerinin Wikipedia benzeri bir uygulama, bloglar ve sosyal ağlar da dahil olmak üzere sosyal medyayı nasıl kullanmaları gerektiği konusunda yönergeler hazırlanmıştır. (Government of Canada, 2011). Güney Afrika hükümeti de, kamu kurumlarının sosyal medyanın faydaları ve riskleri hakkında bilgi sahibi olması için yönergeler hazırlamıştır. Bu yönergeler, hükümet süreçlerinin şeffaflığını, halkın katılımını ve vatandaşlarla etkileşimi artırmak için geliştirilmiştir (South Africa Government, 2011).

Devlet kurumları için sosyal medyanın faydası, Queensland felaketleri ve Haiti depremleri gibi çeşitli vakalarla açıkça görülmüştür. Vatandaş ile hızlı ve verimli bir şekilde irtibata geçilmesi gereken kolluk kuvvetleri, sosyal medyayı, bir alanda veya kampüste gerçekleşen bir suç durumunda bilgiyi yaymak için, bir yangın veya doğal hallerde tahliye talimatları için, belirli uyarılarda bulunmak ve bilgi vermek için kullanmaktadır. Örneğin, 23 Ağustos 2011 'de Virginia'da meydana gelen ama ABD'nin neredeyse tüm doğu sahilini etkileyen, 5.8 büyüklügünde bir deprem meydana gelmiştir. Depremden sadece dakikalar sonra, polis ve acil yardım personeli, Twitter üzerinden halka, nerelerde hasar, yangın ve bina inceleme ve tahliye faaliyeti olduğu gibi konularda bilgi vermişlerdir (Williams and Pittman, 2011).

Tüm bu çabalara rağmen dünyada hala birçok devlet, sosyal medya uygulamalarını tam olarak benimseyememiş ve sistemlerine entegre edememiştir. Kamu sektöründe sosyal medya araçlarının uygulanmasına yönelik engeller ve bu uygulamaların taşıdığı riskler bunda belirleyici olmuştur. Eğer bu riskler bertaraf edilebilir veya en azından minimum seviyeye indirilebilirse, daha çok devlet, sosyal medya merkezli iletişim yoluyla vatandaş odaklı kamu hizmeti uygulamalarını etkin biçimde yerine getirebilir. Çünkü iletişim teknolojilerindeki ilerlemeleri ve özellikle de sosyal medyadaki gelişmeleri dikkate almadan uygulanan politikaların başarılı olma şansı giderek azalmaktadır.

\subsection{Sosyal Medya ve e-Devlet}

Sosyal medyanın vatandaşlara sunduğu etkileşim ve ortak hareket ederek içerik yaratma olanakları, vatandaşların e-devlet uygulamalarında da benzer özellikleri aramasına ve bunları talep etmesine yol açmıştır (Zappen, Harrison and Watson, 2008). Bu bağlamda, edevlet uygulamalarında dönüşüm yaşanmış, e-Devlet 2.0 olarak nitelendirilen ve üst versiyon olarak ifade edilebilecek yeni bir e-devlet uygulaması hayata geçmeye başlamıştır.

Devlet kurumlarınca sosyal medya uygulamalarının kullanılması, kamusal hizmetlerin sayısallaştırma çabalarının uzantısı olduğu söylenebilir (Bretschneider and Mergel, 2010). Sosyal medya uygulamaları, hükümetlerce paydaşlarıyla (özel sektör, STK, vatandaşlar) etkileşime ilave kanal oluşturmak için kullanılmaktadır. Devlet kurumları halkın ilgisini çekmek veya paydaşlarla ilişki kurmak için sosyal medya kanallarına başvurmaktadır (Mergel, 2013).

E-devlet 2.0, geleneksel endüstriyel modelin yansıması olan kamu hizmetlerinin statik ve katı yapısını, bilgi devrimi modeliyle, yenilikçi teknolojilerin etkin kullanımı sayesinde 


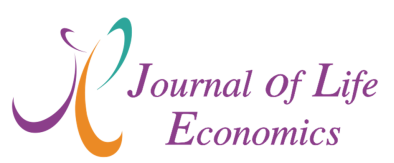

daha dinamik ve etkileşimli hale getirmeye odaklanan yeni bir kavram ve yeni paradigmayı ifade etmektedir. Bu bağlamda, sağlanan hizmetlerin kalitesini artıracak ve hükümeti daha açık ve şeffaf hale getirecektir (Khasawneh and Abu-Shanab, 2013).

E-devlet 2.0, insanların nasıl yaşadığını, nasıl etkileşim kurduğunu, nasıl iletişim içine girdiğini ve çalışmalarını nasıl gerçekleştirdiğini şekillendiren web 2.0 teknolojilerinin küçük çocuğu gibi görülmektedir. E-devlet 2.0, yönetişim, katılımcılık ve istihbarat elde etmede sivil platform olarak kullanılan, bu bağlamda kamu sektörünün özel sektör ve vatandaşlarla, herhangi bir aracıya gerek duymaksızın, birlikte çalışmasına olanak veren bir uygulamadır (Mohamed et al., 2011). Böylece, kamu sektörünün etkinliğini artırması, daha şeffaf ve açık hale getirmesi beklenmektedir.

Sosyal medya, çok kısa bir sürede e-devletin temel bir bileşeni haline gelmiştir. İkinci nesil web hizmetlerinin (Web 2.0) bir yansıması olan sosyal medya araçları, birinci nesil web tabanlı kaynaklardan (Web 1.0) en az üç önemli noktada ayrılır: katılımcıdır, yaygındır ve entegre olma güçleri yüksektir. E-devlet uygulamaları giderek Web 2.0 teknolojisi ve sosyal medya araçlarıyla entegre hale gelmektedir. Abdallah ve Khalil (2009), e-devlet'in web 2.0 hizmetlerinden yararlanabileceği önemli alanların bir listesini sunmuştur. Aşağıda her alanın kısa bir açıklaması verilmiştir:

- Sadece devletin kamusal hizmetleri düzenleme ve kontrol etme rolünü değil aynı zamanda, vatandaşların devletten gerekli düzenlemeleri talep etme gücünü de etkileyen bu uygulamalar, böylece vatandaşların kamusal hizmetlere doğrudan ve açık erişim olanağ 1 vermektedir. Yeni Zelanda polis teşkilatının, vatandaşların yeni uygulamalara yönelik görüsslerini ve önerilerini sunmalarını sağlayan bir wiki uygulaması oluşturması bu tür deneyime bir örnektir.

- Kamu idarelerine web 2.0 hizmetlerini kullanarak kendi iç ve diş etkileşimini artıracakları bir imkan sunar

- Kamu idarelerinin sosyal paylaşım sitelerine katılmasının arkasındaki temel amaç, halk katılımını arttırmaktır. Bu kilit amaca da iki alt amacın gerçekleşmesiyle ulaşılabilir: siyasi katılımı arttırma ve hizmet sunumuna dahil etme. Siyasi katılım, bloglar ve YouTube gibi birkaç web 2.0 hizmeti kullanılarak geliştirilebilir. Örneğin, Barak Obama'nın 2008'deki Amerikan başkanlık seçimlerindeki kampanyasında sosyal ağlar kullanımı genç seçmenlere ulaşmasını sağlamıştır. Hizmet sunumunda ise, wikiler, bloglar ve mash-up haritaları gibi web 2.0 hizmetleri kullanılarak kamusal hizmetlerinin sunumunu ve kalitesini izlemede vatandaşın rolü güçlendirilmeye çalışılır. Böylece, demokratik katılım, denetim, şeffaflık ve hesap verebilirliğin artırılması sağlanabilir. Her iki durumda da e-devlet uygulamalarında sosyal medya araçlarından yararlanılması, e-devletin gerek idari, gerekse siyasi boyutunda vatandaşların pasif katılımdan aktif katılıma, hatta yönetime katılımdan yönetim ile işbirliği düzeyine geçmesinin yolunu açar (Erkul, 2009).

Son araştırmalar sosyal medyanın yönetim süreçlerinin şeffaflı̆̆ını ve demokratikleşmesini kolaylaştırabildiğini göstermiştir. Paydaş ve vatandaşların katılımı, edevletin başarılı bir şekilde uygulanması için en önemli koşullardan biridir. E-devlet uygulamalarının başarı şansını arttırmada sosyal medya araçlarının devletlerin vatandaşlarını ve paydaşlarını cesaretlendiren ve güçlendiren bir tavır sergilemesinde yardımcı olabilir. Edevlet uygulamaları içindeki sosyal medya araçları kamu hizmetlerinin tasarımı, sunumu ve iyileştirilmesinde etkili bir şekilde kullanılabilir. 


\section{SONUÇ VE ÖNERILER}

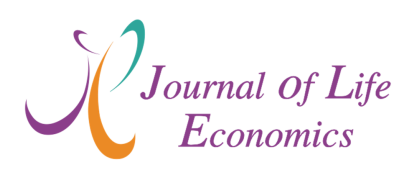

Sosyal medya, devlet kurumlarının kendi arasında, devlet kurumları ve vatandaşlar ile devlet kurumları ve işletmeler arasındaki etkileşim için önemli bir aracı haline gelmektedir. $\mathrm{Bu}$ durum sosyal medyanın açıklık, erişim, katılım, etkileşim ve paylaşım sağlama gibi özelliklerinden kaynaklanmaktadır. Kamu sektöründe sosyal medya kullanımının, teknolojik innovasyon ve dönüşüm sağlayarak yeni olanaklar doğurduğu düşünülmektedir. Sosyal medyanın kamusal hizmetleri genişletme, sivil katılımı arttırma, kitlelerden yenilikçi fikirler alma, karar alma ve problem çözmeyi geliştirme potansiyeli vardır (Khan, Swar and Lee, 2014). Ayrıca, daha şeffaf ve daha demokratik, bir yönetim anlayışı da beraberinde gelecektir. Tüm bu yönleriyle de aslında YKY akımının yansıması olan vatandaş odaklı kamu hizmeti anlayışına hizmet etmektedir. O yüzden sosyal medyanın vatandaş odaklı kamu hizmeti anlayışının gerçekleştirilmesinde belirleyici bir rolü vardır. Hatta sosyal medya bu hizmet anlayışında vatandaşa biçilen rolü de giderek dönüştürmektedir. Vatandaşın rolü hizmetlerin alıcısı olmaktan çıkarak kamu hizmetlerinin ortak üreticisi (co-producer) olmaya doğru gitmektedir.

E-devletten we-devlete (biz-devlete) doğru bir geçiş yaşanırken toplumun devlete daha fazla güven duyduğu "yeni bir sosyal sözleşme türü" ortaya çıkmaktadır diyebiliriz. Çünkü vatandaşlar devletin işleyişinde çok daha aktif bir rol oynamaya başlamaktadırlar. Bu yeni düzenlemeyle de vatandaşlar ve toplumlar daha fazla söz sahibi olma karşılığında daha fazla sorumluluk üstlenirken, kamu idareleri kurallar, platformlar ve erişim imkanları sunmaya devam edecektir (Linders, 2012).

Sosyal medya, devletlerin kamusal hizmetleri şekillendirme ve yerine getirmede önemli bir etkiye sahiptir. O yüzden, sosyal medyanın doğru bir stratejiyle yönetilerek kamu kurumları tarafından kullanılması gerekmektedir. Daha açık bir ifadeyle, bir kamu kurumu sosyal medyayı etkin olarak kullanacaksa, sadece Facebook veya Twitter hesabı açtım bitti dememeli. Bu konuyu bir devlet politikasına dönüştürerek, belirlenen stratejiler ışığında ve gerekli altyapıyı oluşturarak sosyal medyayı her yönüyle ve gerekli her alanda aktif olarak kullanmalıdır. Atari, Stewart-Weeks ve McCalla (2011)'nın da ifade ettiği gibi devletlerin doğru oluşturduğu sosyal medya politikası vatandaşlara daha iyi hizmet ve bilgi erişimi sağlama, onlarla aktif bir iletişim kanalı açma ve sonunda vatandaşları güçlendirerek onları daha fazla politika yapımına dahil etmek suretiyle hükümetlerin daha şeffaf hale gelmesini sağlar. Ayrıca, hükümetler bu tür siteleri etkin ve verimli bir şekilde kullanırsa, vatandaşlara yaşadıkları dünyada daha etkili ve aktif bir katılımcı olma yolunda kapı açacaktır. E-katılım yoluyla, sosyal medya hükümetlere herhangi bir mesajı veya haberi daha etkili ve hızlı bir şekilde iletebilecekleri iletişim kanalları sağlamaktadır. Vatandaşlar, yerel ve ulusal yönetim mekanizmalarıyla kamusal sorunlar konusunda online fikir alışverişinde bulunma, düşüncelerini dile getirme, süreçleri etkileyip şekillendirme ve hatta denetleme imkanına kavuşmaktadırlar. Özellikle sosyal ağlar, halkın gerçek ihtiyaçlarını öğrenmek ve politika ile projeler hakkındaki tavrını görmede idarecilere önemli bir fırsat da sunmaktadır. İhtiyaçların doğru tespiti kıt kaynakların daha verimli kullanılmasını sağlamakta, kırtasiyeciliğin azaltılması ve ihtiyaçların zamanında giderilmesi ile birlikte hizmet kalitesinin arttırılmasına da yardım etmektedir (Yüksel, 2005).

Kamu sektörü için sosyal medya vatandaşlarla etkileşime girmenin yeni bir yöntemi haline gelirken; kamu idareleri sosyal medyanın yararlarını en üst düzeye çıkarmak için sosyal medya çalışmalarının, araçlarının ve analizlerin diğer vatandaş odaklı girişimlerle nasıl entegre edeceklerini düşünmeye başlamışlardır. Bu bağlamda, kamu sektörü sosyal medyayla ilişkili riskleri azaltma, sosyal medyayı anlamlı bir biçimde kullanabilme ve vatandaşla 


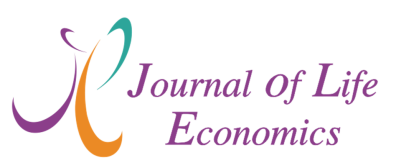

etkileşimde bulunabilme için öncelikle, uzun vadeli bir strateji geliştirilmeli ve vatandaşlara en iyi şekilde ulaşmak için hangi sosyal medya araçlarının kullanılacağına karar verilmelidir. $\mathrm{Bu}$ bağlamda yapılması gerekenlerin başında, altyapı eksiklerinin giderilmesi, uzmanlaşmış ve yetenekli elemanların istihdamının sağlanması ve mevcut personele sosyal medya uygulamaları konusunda eğitim verilmesi gelmektedir. Yetersizlik ve aksaklıkların sık yapılan kontrol ve güncellemelerle giderilmesi, gelişmelerin sürekli takip edilmesi gerekmektedir. Sosyal medya girişimlerini optimize etmek ve faaliyet alanına yönelik destek sağlamak için analiz ve raporlama araçları kullanılmalıdır. Siber güvenliği, olumsuz tanıtım ve diğer başka riskleri yönetmek için bir önlem planı geliştirilmelidir. Sosyal medya stratejisini ve oluşturulan teknolojiyi test etmek, iyileştirme için bir pilot uygulama yapmak çıkarılan dersler 1şı̆̆ında gerekli iyileştirmeleri yapmak gerekmektedir. Ama en önemlisi, vatandaş istek ve beklentilerinin her zaman dikkate alınarak düzenlemelerin bunların 1şı̆̆ında gerçekleştirilmesidir. Devlet, sosyal medya araçlarını otomatikman bünyesine katmamalıdır. Bunun yerine, hangi sosyal medya araçlarının hangi özelliklerini ne ölçüde e-devlet sistemi ile bütünleştireceğini vatandaşlara sormalıdır. Diğer bir değişle, arz odaklı değil, talep odaklı davranmalıdır.

Bunların yanından, sosyal medyanın kamu sektöründe entegrasyonu konusunda başka hususların da göz önünde tutulması gerekmektedir. Öncelikle, sosyal medyayı kamu sektörünün genel iletişim stratejisinin temel bir unsuru olarak tanıyan güçlü politik taahhüt ve liderlik oluşturulmalıdır. Bilgi yönetimi, gizlilik politikası ve siber güvenlik ile ilgili riskleri yönetmek için yasal bir çerçeve oluşturmak gerekmektedir. Sosyal medya araçlarında sergilenen kişisel verilerin mahremiyeti ve kurumsal verilerin gizlilik ve güvenliği ile ilgili kurallar geliştirilerek bunlara vatandaşların uyması sağlanmalıdır. Sosyal medya yoluyla vatandaşlardan görüsş ve geribildirim almak kolaydır. İşin zor tarafı, alınan bu dönüşleri yasalar ve uygulamaların içine yedirmek kısmıdır. Ayrıca, belirli ihtiyaçları ve beklentileri karşılamak için belirli amaçlara yönelik ve sektörel sosyal medya politikaları belirlenmelidir. Herhangi bir sosyal medya politikası ise mevcut kurum politikalarına ve genel iletişim stratejisine göre düzenlenmedir.

Teknolojiye erişimi olmayan ve teknolojiyi katma değer elde edecek şekilde kullanamayan kitlelerin sorununu ifade eden "bilişim uçurumu" kavramı, sosyal medya için de geçerlidir. Kamusal bilgi ve hizmetler sosyal medya yoluyla sunulursa, sosyal medyaya erişemeyenlerin veya sosyal medya araçlarını kullanmayı tercih etmeyenlerin durumu ne olacaktır? Öncelikle bu soruya yanıt bulunması, sosyal medya uygulamalarının herkes tarafından kullanılır hale getirilmesi gerekmektedir. Ayrıca, sosyal medya araçları, sadece şu anda mevcut hizmetlere yönelik bir geribildirim kanalı olarak kalmamalı, başka ne gibi kamusal bilgi ve hizmetlerin hangi yenilikçi yöntem ve teknolojilerle verilebileceğini sorgulayan bir yapıya kavuşmalıdır (Bertot et al., 2010a).

Sosyal medya uygulamaları, bloglara yorum yükleyebilme, mesaj bırakabilme, devlete ait Facebook fan sayfalarında içerik oluşturabilme, bir kurum tarafından tweetlenen içeriği yeniden kullanabilme veya içeriği takipçilerine iletebilme gibi kullanıcılara çok sayıda imkan sağlar. Hem vikiler örneğinde olduğu gibi kamu kurumları arasında bilgi paylaşım mekanizmalarıyla hem de vatandaşlarla yeni tür etkileşim biçimlerine imkan veren kurum dışı bilgi paylaşım araçlarıyla iki yönlü etkileşimi olanaklı kılar. Sosyal medya uygulamalarının benimsenmesi, piyasa merkezli ve vatandaş odaklı e-devlet uygulamalarını geliştirmekte; ancak yenilikçilik derecesi ve ne kadar benimsendiği büyük ölçüde değişmektedir. Tabi şu bir gerçektir ki sosyal medya uygulamaları, piyasa/vatandaş odaklı iletişimi geliştirmede yeni bir firsat sunmaktadır (Mergel, 2013). 


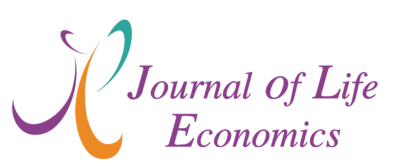

Sosyal medyanın kamu idarelerinin ve bireylerin birbirleriyle nasıl iletişim kurdukları konusunda önemli bir değişim yarattığı açıktır. Bu değişim kamu sektörü için hem fırsatlar hem de tehditler yaratmaya devam edecektir. Devlet organları bu gerçeğe paralel olarak, kendilerine sosyal medya politikaları oluşturmaktadır. Türkiye'de bu durumun önemi tam manasıyla anlaşılamamıştır, ama sosyal medyanın gün geçtikçe yaygınlaşan kullanımı sonucunda, bu tür politikalara daha çok yönleneceği düşünülmektedir. Düzgün bir planlama ve etkili bir koordinasyon ile öncelikle bakanlık web sayfalarından başlayarak ülke geneline bu platformlar yaygınlaştırılmaya başlamıştır.

Bazı devlet kurumlarının yaptığı yanlışlık ise sosyal medyayı maalesef bilgi işlem ,sorumlularına eline bırakmasıdır. Bu yapılabilecek en büyük yanlışlıktır. Sosyal medya ayrı bir mercidir, ya bu konuda danışmanlık alınmalı ya da sadece bunun eğitimini almış kişiler bu departmana verilmelidir. Görev bu konuda eğitim almış kişilere ya da eğitim yoksa eğitim alması sağlanmalıdır. Kurumlar bunları da yapmıyorsa dışarıdan danışmanlık almalıdır. Bundan dolayıdır ki çoğu kamu kurumu sosyal medyayı kullanmıyorlar bile (USMED, 2017).

Kamu sektöründe sosyal medyayı kullanımı her konu kurum, vatandaş ve devlet için standart kuralları olmayan bulanık ve öznel bir sorundur. Bazıları, sosyal medyada başarının, dünya çapındaki hükümetlerin mevcut yapısında sürdürülemeyeceğini düşünmektedir. Devlete ilişkin hukuki düzenlemelerin, teknolojik altyapının, insan kaynaklarının ve en önemlisi devlet kültürünün dönüştürülmesi gerekmektedir. Vatandaş odaklı hizmet anlayışı çerçevesinde kamusal hizmetlerin şekillendirilmeye çalışıldığı bir dönemde devlet yapısının sosyal medya uygulamalarına göre şekillendirmek zorunluluk haline gelmiştir.

Vatandaş odaklı kamu hizmeti anlayışının kolay erişim, şeffaflık, hesap verebilirlik, kalite, etkililik gibi birçok unsurunun gerçekleşebilmesinde sosyal medya giderek kilit bir rol oynamakta, hatta vatandaş odaklı hizmet anlayışı içinde vatandaşa atfedilen "müşteri" kimliği yerine "ortak üretici" kimliği getirmektedir. Diğer bir ifadeyle, sosyal medya çağında vatandaşlar artık kamu hizmetlerinin tasarlanması ve gerçekleştirilmesinde devletin bir ortağı haline gelmektedir. Sosyal medya uygulamaları bir yandan vatandaş odaklı kamu hizmeti anlayışına hizmet ederken, bir yandan da onu dönüştürmektedir. Ama şu açıktır ki, söz konusu hizmet anlayışı için sosyal medya vazgeçilmez olma yolunda ilerlemektedir. Son dönemde birçok ülkede kamu idarelerin web sitelerini incelediğimizde muhakkak bu uygulamalara yer verildiği görülürken; e-devlet hizmetleriyle de sosyal medya uygulamaları arasında bir entegrasyon sağlanmaya çalışılmaktadır. Siyasilerin de bu uygulamalara sıkça başvurmaya başlaması bir tesadüf değildir.

Tüm bunların 1şığında kamu sektöründe sosyal medya uygulamalarının vatandaş odaklı kamu hizmeti anlayışına hizmet edebilmesi için öncelikle kamu kurumlarının kullandığı sosyal medya araçlarının kolay ulaşılabilir olması gerekmektedir O yüzden araç çeşitliği, bunlara kurumların kendi web sitelerinde nasıl yer verildiği ve ne kadar aktif yönetilip güncellendiği gibi konular önem arz etmektedir. Bunun yanında, yayınlanan içeriklerin kaliteli, basit ve anlaşılabilir olması gerekmektedir. Sosyal medya aracılığıyla ulaşılmak istenen kitle ile arada empati yapılmalı, sık sık etkileşeme geçilip (yorumlara yanıt verme, online mesajlaşma yöntemlerini kullanma gibi) kitlenin istek ve beklentileri maksimum düzeyde karşılanmaya çalışılmalıdır. Söz konusu araçlarla kamu idarelerinin sunduğu hizmetler, yaptığı kampanyalar ve verdiği reklamlar inandırıcı olmalıdır. Ama en önemlisi kamu idarecileri sosyal medya araçlarının gerekliliğini kabul etmeli ve bu yöndeki politikaları desteklemelidir.. 


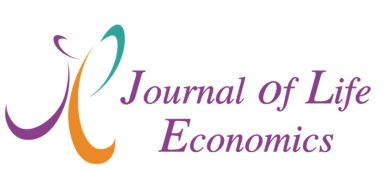

\section{KAYNAKÇA}

ABDALLAH, S. and KHALİL, A., 2009, "Web 2.0 and E-Governments: An Exploration of Potentials \& Realities In The Arab World", Proceeding of European and Mediterranean Conference on Information Systems (EMCIS2009), Crowne Plaza Hotel, Izmir, July 13-14.

AGOSTINO, D., 2013, "Using Social Media to Engage Citizens: A Study of Italian Municipalities", Public Relations Review, 39, 232-234

AL-BADI, A. H., 2014, "The Adoption of Social Media in Government Agencies: Gulf Cooperation Council Case Study". Journal of Technology Research, 5(1), 1-26.

ATARI, S., STEWART-WEEKS, M. and MCCALLA, J., 2011, Web 2.0 in Next-Generation Government and Governance: A Middle East Point of View. Cisco Internet Business Solutions Group (IBSG).

BAKER, F. P., 1995, "Marketing in a Local Authority", Journal of Marketing Practice: Applied Marketing Science, 1 (4), 73-84.

BAUMGARTNER, J. C., \& MORRIS, J. S., 2010, "My Facetube Politics: Social Networking Web Sites and Political Engagement of Young Adults", Social Science Computer Review, 28, 24-44.

BERTOT, J. C., JAEGER, P. T., and HANSEN, D., 2012, "The impact of Policies on Government Social Media Usage: Issues, Challenges, and Recommendations", Government Information Quarterly, 29, 30-40.

BERTOT, J.C., JAEGER, P.T. and GRIMES, J.M., 2010, "Using ICTs to Create a Culture of Transparency: e-Government and Social Media as Openness and Anti-Corruption Tools for Societies", Government Information Quarterly, 27, 264-271.

BERTOT, J. C., JAEGER, P. T., MUNSON, S. and GLAISYER, T., 2010a, "Social Media Technology and Government Transparency", Computer, November, 55-59.

BERTOT, J. C., JAEGER, P. T., MUNSON, S., and GLAISYER, T., 2010b, "Engaging the Public in Open Government: The Policy and Government Application of Social Media Technology For Government Transparency". IEEE Computer, 43(11), 53-59.

BRETSCHNEIDER, S. I. and MERGEL, I., 2010, “Technology and public management information systems: Where have we been and where are we going", Menzel, D. C. and H. J. White (Eds.), The State of Public Administration: Issues, Problems and Challenges, New York: M.E. Sharpe, Inc, 187-203.

BRYER, T. A, and ZAVATTARO, S. M., 2011, "Social Media and Public Administration", Administrative Theory \& Praxis, 33(3), 325-340.

CANADIAN CENTRE FOR MANAGEMENT DEVELOPMENT, 1999, Citizen Centred Service: Responding to the Needs of Canadians for the Citizen-Centred Service Network. http://www.iccsisac.org/en/pubs/CCHandbook.pdf (Erişim Tarihi: 11.08.2017)

CHUN, S. A., SHULMAN, S., SANDOVAL, R., and HOVY, E., 2010,. "Government 2.0. Making Connections Between Citizens, Data and Government. Information Polity", The International Journal of Government \& Democracy in the Information Age, 15, 19. 


\section{$\int\left(\begin{array}{c}\text { Journal of Life } \\ \text { Economics }\end{array}\right.$}

COI, 2011, Engaging through Social Media: A guide for civil servants, London: Hercules House.

CRIADO, I., SANDOVAL-ALMAZAN, R. and GIL-GARCIA, J. R., 2013, "Government Innovation through Social Media", Government Information Quarterly 30, 319-326..

ÇUKURÇAYIR, M. A., 2009, Yurttaş Odaklı Yerel Yönetim, Konya: Çizgi Kitabevi.

DADASHZADEH, M., 2010, "Social Media in Government: From e-Government to eGovernance", Journal of Business \& Economics Research, 8, 81-86.

DESCHAMPS, R., MCNUTT K. and ZHU, W. (Eds.), 2012, Environmental Scan on Social Media Use by the Public Sector Administration, Public Engagement and Citizen Centered Services, Johnson-Shoyama Graduate School of Public Policy, University of Saskatchewan, October 21, http://www.schoolofpublicpolicy.sk.ca/resources/Government/Environmental\%20Sca n\%20on\%20Social\%2Media\%20in\%20the\%20Public\%20Sector/Environmental\%20S can\%20of\%20Social\%20Media\%20Use\%20in\%20Governments_pdf.pdf (Erişim Tarihi: 21.08.2017)

DPT (Devlet Planlama Teşkilatı), 2006, Bilgi Toplumu Stratejisi (2006-2010), Ankara.

DUGGAN, M., 2010, Citizen Centred Service Delivery, Curam Software, http://www.curamsoftware.ca/sites/default/files/doc_files/USENWP-CCSD.pdf (Erişim Tarihi: 11.07.2017).

ERKEK S., 2016, "Kamu Kurumlarında Sosyal Medya Kullanımı: Sağlık Bakanlığı Örneği”, Selçuk Ün. Sosyal Bilimler Enstitüsü. Dergisi 35, 141-150.

ERKUL, R. E., 2009 "Sosyal Medya Araçlarının ( Web 2.0 ) Kamu Hizmetleri ve Uygulamalarında Kullanılabilirliği”, Türkiye Bilişim Derneği, 116 (Aralık), 96-101.

FALCO, T., 2011, "Taking Social Media Public: Social Media for Successful Citizen Relationship Management”, IBM Global Business Services White Paper, USA: IBM Corporation.

GOVERNMENT OF CANADA, 2011, Guidelines for Secure External Use of Web 2.0, http://www.tbs-sct.gc.ca/pol/doc-eng.aspx?section=text\&id=24835(Erişim Tarihi: 21.08.2017)

KAPLAN, A. M., and HAENLEIN, M. 2010. "Users of The World, Unite! The Challenges and Opportunities of Social Media", Business Horizons, 53(1), 59-68.

KARATAŞ, H., 2007, "Kamu Yönetiminde Yeni Bir Anlayış: Vatandaş Odaklı Yönetim”, Bütçe Dünyast, 24, 83-94.

KENT, M. L., 2010. "Directions in Social Media for Professionals and Scholars". R. L. HEATH (Ed.), Handbook of Public Relations, Thousand Oaks, CA: Sage, 2nd ed., 643-656.

KHAN, G. F., 2015, "The Government 2.0 Utilization Model and Implementation Scenarios", Information Development, 31(2), 135-149.

KHAN, G. F., SWAR, B. and LEE, S. K., 2014, "Social Media Risks and Benefits: A Public Sector Perspective”, Social Science Computer Review, 32(5), 606-627. 


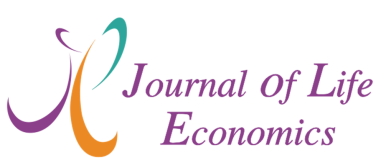

KHASAWNEH, R. T. and ABU-SHANAB, E. A.,2013,"E-Government and Social Media Sites: The Role and Impact”, World Journal of Computer Application and Technology, $1(1), 10-17$.

KIETZMANN, J.H., HERMKENS, K., MCCARTHY, I.P., and SILVESTRE, B.S., 2011, "Social media? Get serious! Understanding the functional building blocks of social media", Business Horizons, 54, 241-251.

KLIEBER, P., 2009, "Document Classification Through Data Mining Social Media Networks", A Senior Research Paper, http://digital.archives.stetson.edu/cdm/ref/collection/Research/id/2097 (Erişim Tarihi: 11.07.2017).

KOTLER, P., KARTAJAYA, H., and SETIAWAN, I., 2010, From Products to Customers to the Human Spirit: Marketing 3.0. Hoboken: John Wiley \& Sons.

LANDSBERGEN, D., 2010, "Government as Part of the Revolution: Using Social Media to Achieve Public Goals", Electronic Journal of e-Government, 8(2), 135-147.

LEE, G. and KWAK, Y. H., 2012, “An Open Government Maturity Model for Social MediaBased Public Engagement”, Government Information Quarterly, 29, 492-503.

LERMAN, K., 2007, "Social Information Processing in News Aggregation", IEEE Internet Computing, 11(6), 16-28.

LINDERS, D., 2012,. "From E-Government to We-Government: Defining a Typology for Citizen Coproduction in the Age of Social Media", Government Information Quarterly, 29(4), 446-454.

MAYFIELD, A. 2008, What is Social Media, U.K: iCrossing. http://www.icrossing.com/sites/default/files/what-issocial-media-uk.pdf $\quad$ (Erişim Tarihi: 18.07.2017).

MEIJER, A. J., 2011, "Networked Coproduction of Public Services in Virtual Communities: From a Government-Centric to a Community Approach to Public Service Support." Public Administration Review 71(4), 598-607.

MERGEL, I., 2013, A framework for Interpreting Social Media Interactions in the Public Sector", Government Information Quarterly, 30, 327-334.

MERGEL, I., 2012, “A Manager's Guide to Designing a Social Media Strategy”, IBM Special Report Series, NW: IBM Center for the Bussiness of Government, http://faculty.maxwell.syr.edu/iamergel/files/Social\%20Media\%20Strategy\%20Brief 0\%20(1).pdf (Erişim Tarihi: 17.01.2017).

MERGEL, I., 2010, “Gov. 2.0 Revisited: Social Media Strategies in the Public Sector", PA Times, Summer 2010, 7-8.

MOHAMED, F., MUTHAIYAH, S. and NASSIRTOUSSI, A., 2011, "TM: A Development Technique for E-government 2.0 Portals", Wseas Transactions on Information Science and Applications, 8 (2), 96-108.

O'REILLY, T. 2005, "What Is Web 2.0: Design Patterns and Business Models for the Next Generation of Software". O'Reilly Media. http://www.oreillynet.com/pub/a/oreilly/tim/news/2005/09/30/what-is-web-20.html (Erişim Tarihi 15 Ağustos 2017) 


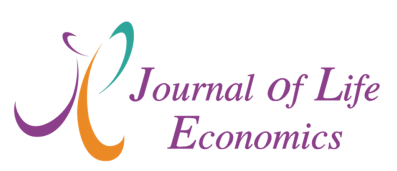

OSBORNE, D. and GAEBLER, T., 1992, Reinventing Government: How the Entrepreneurial Spirit is Tranforming the Public Sector, USA: A William Patrick Books, 2. Edition.

PICAZO-VELA， S. GUTIÉRREZ-MARTINEZ， I. and LUNA-REYES, L. F., 2012, "Understanding Risks, Benefits, and Strategic Alternatives of Social Media Applications in the Public Sector", Government Information Quarterly, 29, 504-511

REICHARDT, A., 2010. "Public Management in the Age of Social Media. An Analysis of Web 2.0 Tools as Platforms of Public Administration in Poland and Abroad", Wspólczesne Zarządzanie, No: 3, 92-102.

RESSLER S., 2009, The Emergence of Gov 2.0: From GovLoop to the White House, [in:] J. Gotze and C.B. Pedersen (eds.), State of the eUnion, Bloomington, IN: Author House, Bloomington, IN.

RICHARDS, R., 2010, "Digital Citizenship and Web 2.0 Tools", MERLOT Journal of Online Learning and Teaching, Vol.6(2), 516-522.

SAFKO, L., 2009, The Social Media Bible: Tactics, Tools and Strategies for Business Success, New Jersey: John Wiley \& Sons, Inc.

SANDSMARK, F., 2011, From Social Media to Social Commerce. Digital Marketing

SAYGILIOĞLU N. ve ARI, S., 2003, Etkin Devlet / Kurumsal Bir Tasarı ve Politika Önerisi, İstanbul: Sabancı Üniversitesi Yayınları.

SERRAT, O. 2010, "Social Media and the Public Sector", Knowledge Solutions, 83 (April), $1-8$

SHIRKY, C., 2011, "The Political Power of Social Media: Technology, The Public Sphere, and Political Change", Foreign Affairs, January/February, https://www.foreignaffairs.com/articles/2010-12-20/political-power-social-media (Erişim Tarihi: 21.08.2017).

SOLIS, B. and BREAKENRIDGE, D., 2009, Putting the Public Back in Public Relations, New Jersey: Pearson Education.

SOUTH AFRICA DEPARTMENT OF PUBLIC SERVICE AND ADMINISTRATION, 2003, Batho Pele Handbook: A Service Delivery Improvement Guide, http://www.kzneducation.gov.za/Portals/0/documents/BathoPeleHandbook.pdf (Erişim Tarihi: 10.06.2017).

SOUTH AFRICA GOVERNMENT, 2011, Social Media Policy Guidelines, http://www.gcis.gov.za/resource_centre/guidelines/ social_media_guidelines_final_20_april2011.pdf (Erişim Tarihi: 21.08.2017)

STERN, S. and IBARRA, P., 2011, "Digital Government: Creating the Social Media Game Plan", Government Finance Review, October, 9-14.

TAŞÇI, E., 2010, "Sosyal Medya Araçlarının Yerel Yönetimlere Etkisi ve Katkısı: Belediye 2.0”, Türkiye Bilişim Derneği Biliş̧im Dergisi, 38 (126), 23-26.

USMED, 2017, "Devlet Kurumları ve Sosyal Medya", Uluslararası Sosyal Medya Dergisi (USMED), http://usmed.org.tr/devlet-kurumlari-ve-sosyal-medya/ (Erişim Tarihi: 07.09.2017).

UYSAL ŞAHİN, Ö., 2014, Kamu Ekonomisi Perspektifinden Vatandaş Odaklı Kamu Hizmeti Yaklaşımı, Ankara: Seçkin Yayıncılık. 


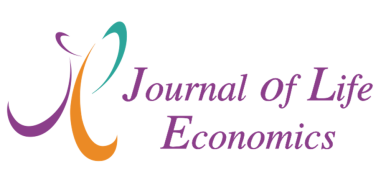

WILLIAMS, M. and PITTMAN, E., 2011, "Virginia Earthquake Sets off Wave of Emergency Tweets", Government Technology, http://www.govtech.com/e-government/VirginiaEarthquake-WaveofEmergencyTweets.html?elq=d83463f93f074fff8d1671d02a5369dc (Erisim Tarihi: 26.08.2017)

World-Class Public Services: Engaging Citizens and Staff, 2017, http://theworkfoundation.com/Assets /Docs/adobe_world_class_final.pdf (Erişim Tarihi: 25.08.2017)

YÜKSEL, F., 2005, “Bilgi Teknolojileri ve Yerel Yönetimler”, Selçuk Üniversitesi Sosyal ve Ekonomik Araştırmalar Dergisi, 10, 247-259.

ZAPPEN, J. P.; HARRISON, T. M. and WATSON, D., 2008, "A new Paradigm for Designing E-Government: Web 2.0 and Experience Design", TheProceedings of the 9th Annual International Digital Government ResearchConference, 17-26. 